Véronique Zech-Matterne, Girolamo Fiorentino, eds.

\title{
AGRUMED
}

Archaeology and history of citrus fruit in the Mediterranean:

Acclimatization, diversifications, uses

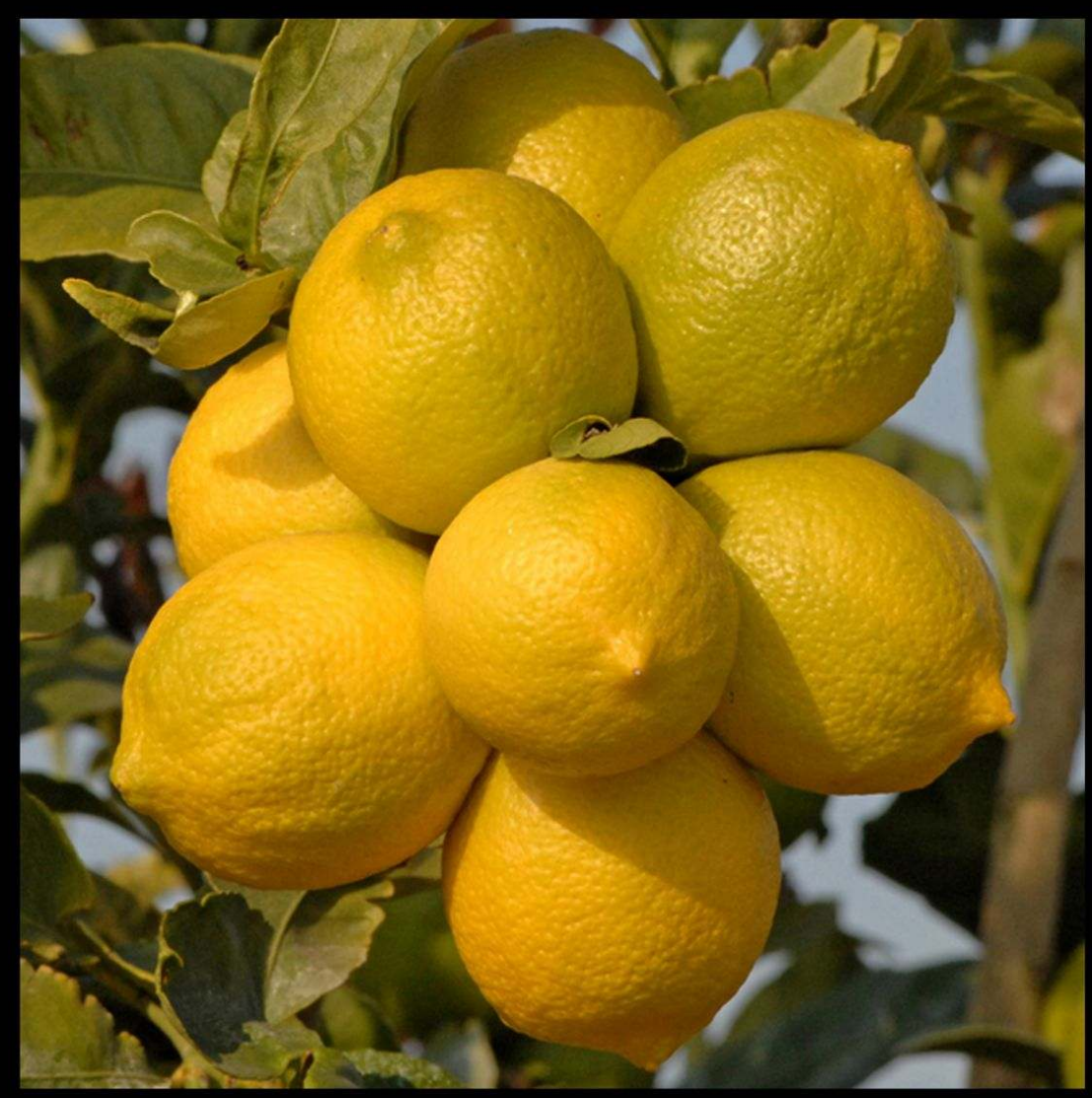

CNRS COLLECTION DU CENTRE JEAN BÉRARD, 48 ÉFR 


\section{AGRUMED: Archaeology and history of citrus fruit in the Mediterranean}

Acclimatization, diversifications, uses

\section{Véronique Zech-Matterne and Girolamo Fiorentino (dir.)}

DOI: 10.4000/books.pcjb.2107

Publisher: Publications du Centre Jean Bérard

Place of publication: Naples

Year of publication: 2017

Published on OpenEdition Books: 15 January 2018

Serie: Collection du Centre Jean Bérard

Electronic ISBN: 9782918887775

\section{Sobooks}

http://books.openedition.org

\section{Electronic reference}

ZECH-MATTERNE, Véronique (ed.) ; FIORENTINO, Girolamo (ed.). AGRUMED: Archaeology and history of citrus fruit in the Mediterranean: Acclimatization, diversifications, uses. New edition [online]. Naples:

Publications du Centre Jean Bérard, 2017 (generated 17 January 2018). Available on the Internet: <http://books.openedition.org/pcjb/2107>. ISBN: 9782918887775. DOI: 10.4000/books.pcjb.2107.

This text was automatically generated on 17 January 2018.

(c) Publications du Centre Jean Bérard, 2017

Terms of use:

http://www.openedition.org/6540 
The book brings together 16 contributions on the ancient and recent history of citrus fruits. Although they represent the main fruit production on a worldwide scale, very little is known about their original domestication and routes of introduction into the Mediterranean and temperate Europe: few organic remains identified as citrus have been found on archaeological sites. Nevertheless, evidence has been retrieved for various periods in the form of pollen grains, seeds, rind fragments, and occasionally wood and whole fruits in areas of primo-domestication, Asian, and from sites along the potential routes of diffusion. Iconographic figurations and textual references also exist. The contributions presented here - written by researchers specializing in phylogeny, taxonomy, morphometry, archaeobotany, history, iconography, the study of classical letters, and curators of collections - present the latest knowledge relating to the taxonomy of the Citrus genus and the methods used in attempting to identify ancient specimens. Analysis of botanical remains and a variety of other sources, has allowed the citrus diversity in China, India, Israel, Egypt, Italy, and North-West Europe to be described. Greek, Latin and medieval texts have been explored in order to identify recognized species, cultivation methods, modes of consumption, uses, and virtues attributed to citrus fruits since their first occurrences. The conservatories and germplasm collections of citrus are presented from a historical point of view, as are the important role they play in genetic research to improve cultivars, the conservation of rare and ancient varieties, and the role of informing the general public is also emphasized. The symbolic representation of citrus fruits in the arts, literature, and philosophy completes this overview, and fills a gap concerning these emblematic Mediterranean fruit.

L'ouvrage rassemble seize contributions relatives à l'histoire ancienne et récente des agrumes. Alors qu'ils représentent la première production fruitière à l'échelle mondiale, peu de travaux ont été menés sur leurs aires d'origine et leurs voies de diffusion, car très peu de vestiges organiques correspondant à des restes d'agrumes ont été découverts dans les sites archéologiques. Néanmoins, des témoins subsistent pour diverses périodes, sous la forme de pollens, semences, fragments d'écorce, occasionnellement bois et fruits entiers, dans les zones de primo-domestication, asiatiques, et dans les sites jalonnant les routes potentielles de dissémination de ces espèces vers la Méditerranée et l'Europe tempérée. Il en existe également des représentations iconographiques et des mentions textuelles. Les présentes contributions - rédigées par des spécialistes de génétique, taxinomie, morphométrie, archéobotanique, histoire, iconographie, lettres classiques, mais aussi des conservateurs de collections archéologiques et actuelles - présentent les dernières connaissances en matière de classification et de tentatives d'identification des restes anciens, ainsi que des synthèses qui mettent en valeur l'ensemble des témoins, ou certains indices particulièrement remarquables, de la diversité des agrumes en Chine et Inde, Israël, Égypte, Italie, Europe du Nord-Ouest. Les sources grecques, latines et médiévales sont également mises à contribution pour mieux appréhender les espèces reconnues, les modes de culture et de consommation, les usages et vertus attribués aux agrumes depuis leurs premières occurrences. Les conservatoires et grandes collections d'agrumes sont présentés du point de vue historique, et l'importance du rôle joué par ceux-ci dans la recherche génétique visant à améliorer les cultivars, la conservation de certaines variétés et l'information du public, est soulignée. Un éclairage sur la représentation symbolique des agrumes dans les arts, la littérature et la philosophie, complète ce tour d'horizon, qui vient combler un vide concernant des espèces particulièrement emblématiques de la Méditerranée. 


\section{TABLE OF CONTENTS}

Preface

Massimo Osanna

Introduction to 'AGRUMED: Archaeology and history of citrus fruit in the Mediterranean: Acclimatization, diversification, uses'

Véronique Zech-Matterne, Girolamo Fiorentino, Sylvie Coubray and François Luro

Recent insights on Citrus diversity and phylogeny

François Luro, Franck Curk, Yann Froelicher and Patrick Ollitrault

1. Taxonomy

2. Geographical origins

3. Phylogeny of edible Citrus species

4. Diversification

Conclusion

Charred pummelo peel, historical linguistics and other tree crops: Approaches to framing the historical context of early Citrus cultivation in East, South and Southeast Asia Dorian Q. Fuller, Cristina Castillo, Eleanor Kingwell-Banham, Ling Qin and Alison Weisskopf

1. Origins inferred from genetics and biogeography

2. Early Historic evidence from China

3. Historical linguistic evidence from India

4. Limitations of the published archaeobotanical record

5. New evidence from archaeological rind finds

6. Discussion: The tree crop transition, crafts and trade

The earliest evidence for citrus in Egypt

Charlène Bouchaud, Jacob Morales, Valérie Schram and Marijke van der Veen

1. Archaeobotanical remains of citrus

2. Text references to citrus

3. Discussion

Conclusion

The history of Citrus medica (citron) in the Near East: Botanical remains and ancient art and texts

Dafna Langgut

1. Archaeobotanical evidence

2. Textual evidence

3. Ancient art artefacts

4. Suggested C. medica diffusion route

5. Summary

Investigating the introduction of citrus fruit in the Western Mediterranean according to ancient Greek and Latin texts

Clémence Pagnoux

1. Names of citrus fruit in Greek and Latin texts

2. Descriptions and properties of the plant

3. Clues to ancient perception of citrus fruit

Conclusion

Painted gardens: Observations on execution technique

Ernesto De Carolis 
Pollen morphology reveals the presence of Citrus medica and Citrus $\mathrm{x}$ limon in a garden of Villa di Poppea in Oplontis ( $1^{\text {st }}$ century BC)

Elda Russo Ermolli, Bruno Menale and Maria Rosaria Barone Lumaga

1. The introduction of Citrus to the Mediterranean according to Pliny and other classical authors

2. Material and methods

3. Results

4. Discussion

Conclusion

Macroremains of citrus fruit in Italy

Alessandra Celant and Girolamo Fiorentino

1. Citrus finds at Pompeii

2. Citrus finds in Rome

3. Discussion and conclusions

Quantitative evaluation of modern Citrus seed shape and comparison with archaeological remains discovered in Pompeii and Rome

Anna Maria Grasso, Fabio Mavelli and Girolamo Fiorentino

1. Materials

2. Methods

3. Results

4. Discussion and research perspectives

Citrium: A miraculous fruit. Investigating the uses of citrus fruit in the Western Mediterranean according to ancient Greek and Latin texts

Clémence Pagnoux

Citrus fruit in historical France: Written sources, iconographic and plant remains Marie-Pierre Ruas, Perrine Mane, Charlotte Hallavant and Michel Lemoine

1. Limits and complementary nature of the medieval sources

2. Citrus fruit through the illustrations and texts of medieval Europe

3. Archaeobotannical evidence of citrus fruit in France

Conclusion

The history of Citrus in the Low Countries during the Middle Ages and the Early Modern

Age

Wouter van der Meer

1. Citrus in the Low Countries in the period before the late Middle Ages

2. Late medieval historical sources concerning Citrus

3. Historical sources on Citrus in the early modern age

4. Archaeobotanical evidence for Citrus in the Low Countries

Summary

The humanistic tradition of citrus culture in Central Europe from the $15^{\text {th }}$ to the $18^{\text {th }}$ century Helmut-Eberhard Paulus

1. Humanism

2. The Golden Apples

3. A humanistic way of life

4. Architecture of the orangery

Research on and maintenance of the modern-day citrus collections in Germany and Austria Claudia Gröschel 
The INRA-CIRAD citrus germplasm collection of San Giuliano, Corsica

François Luro, Emmanuel Bloquel, Bruno Tomu, Gilles Costantino, Isabelle Tur, Simone Riolacci, François Varamo, Patrick Ollitrault, Yann Froelicher, Franck Curk and Olivier Pailly

1. Establishment of a healthy citrus collection in San Giuliano

2. Richness of the SRA citrus repository

3. Flow of shipped material from the citrus repository

4. Characterization and evaluation of accessions

5. Major research undertaken courtesy of the INRA-CIRAD citrus collection

6. Certification of the INRA-CIRAD citrus collection

7. Computerization of the citrus genetic resource management

8. Perspective in security and long-term storage/concept of core collection

9. The citrus germplasm as a communication and education support

Conclusion 


\title{
Citrus fruit in historical France: Written sources, iconographic and plant remains
}

\author{
Marie-Pierre Ruas, Perrine Mane, Charlotte Hallavant and Michel \\ Lemoine
}

1 Citrus genus fruit remains have been found in the form of pollen, pericarp fragments and seeds at several sites dated from antiquity and the Middle Ages in the Mediterranean Basin, particularly in Egypt and Italy. ${ }^{1}$ In temperate Europe, such remains have only been recorded since the end of the Middle Ages in urban site sediment strata. ${ }^{2}$ Until recently, no archaeobotanical remains had proven that these fruits had been consumed at any time in France, although it was explicitly stated in several medieval written sources. ${ }^{3}$ This is even more surprising considering that in Roman Gaul some exotic species such as the date, the peach, the sebesten plum, the pomegranate, the mulberry tree and the pepper have been identified among the remains of food waste or in the deposits of mourning rituals and funerary ceremonies. ${ }^{4}$ However, recently Citrus remains have been discovered in an urban cesspit in Bordeaux which was used during the $18^{\text {th }}$ century. ${ }^{5}$

2 As both written and iconographical sources have suggested, ${ }^{6}$ several species of citrus were consumed, traded and maybe even cultivated in the gardens of the medieval French elite: the citron tree, the lemon tree, the lime tree, the sour orange tree, the sweet orange tree, the mandarin tree and probably the grapefruit tree. This article focuses on citrus fruit from a part of medieval Europe that is well covered by written and iconographical sources, and presents both these fruit and this unique Citrus seed discovery in France. After having defined the limits of the consulted records, we will comment on the knowledge that the medieval sources provide on fruit trees and their fruit, their symbolic meaning within a French-Christian context, the places exploited and the growing methods used, their economic status, commercialization and citrus fruit eating habits. Archaeobotanical remains and their preservation modes are described and discussed within their $18^{\text {th }}$ century context. 


\section{Limits and complementary nature of the medieval sources}

\subsection{The written sources}

In the medieval archives, terms referring to fruit or to the botanical genus Citrus come from different areas: agronomical, recipe collection (réceptaires) or medical treatises, urban bylaws, royalties, expense accounts, merchant tariffs (leudes), herbariums and botanical encyclopaedias, etc. This diversity of documentation concerns society at large, even if the culinary treatises mostly concern the food consumption of the highest levels of aristocracy.

4 Before a statistical evaluation of the place of fruits, in particular citrus fruit, can be made, it is necessary to take into account the relativity of the witness accounts. ${ }^{7}$ First of all, from one treatise to another the contents can be quite different, due to the variety of authors and the types of audiences targeted. Certain réceptaires are the works of minor lords, others come from the simple bourgeoisie (middle-class citizens), as in the case of $L e$ Ménagier de Paris. Others, on the contrary, are signed by the chefs of royal families such as Taillevent, alias Guillaume Tirel, who reproduced recipes from Le Viandier. Réceptaires seem to primarily have been used for reporting the prestigious foods served at the tables of the nobles. One of the characteristics of medieval aristocratic cuisine was cosmopolitanism, and indeed the same foods are to be found in most of the western treatises. ${ }^{8}$ Another problem with the réceptaires is that they were not dated or the dates were approximate and, having often been lent or borrowed, they contain added notes which were then shared and passed among the treatises. In fact certain recipes, or rather the names of the recipes, were hardly changed in all or almost all of the references, ${ }^{9}$ and it was not until they were written down that they were subject to numerous transformations by the copyists of the time.

5 As for the vernacular vocabulary used in the different records it is difficult to assign the correct names to the citrus fruits cited. Which species of orange were referred to in the Italian treatises of the $14^{\text {th }}$ and $15^{\text {th }}$ centuries when "arancia", cited more rarely as " pomarancia", becomes "melerancia" on a list of items purchase by the Lords of Florence in the $15^{\text {th }}$ century? ${ }^{10}$ This last term "melerancia" is referred to as "pommes oranges" by the Parisian bourgeois who wrote Le Ménagier de Paris at the end of the $14^{\text {th }}$ century.

In reference to the adjectives which are used to define the arancia or pomarancia, it is likely that these works describe the sour orange (Citrus $\mathrm{x}$ aurantium) and its acidic juice. ${ }^{11}$

The meaning of the words "citrangole" (or "cetrangole") or even "melangole" is more difficult to specify, but they were used very frequently at the beginning of the $14^{\text {th }}$ century in Liber de Coquina ${ }^{12}$ where no derivatives of arancia are found. These two terms designate two different fruits in Libro della cocina, composed in Tuscany at the end of the $14^{\text {th }}$ century, in which the chef proposed to use one of the two fruits in the recipe Pastello de le trote e d'altri pesci where, when the fish is well cooked, it is necessary to add "aqua rosata, ovvero succhio d'aranci o di citrangole". ${ }^{13}$ For B. Laurioux, ${ }^{14}$ "citrangole" could refer to the citron; and indeed the term 'citrus' seems to have become a generic term designating all citrus fruits which resembled a citron in appearance and taste. The chef, Bockenheim, gave the name "pomi citri" to the citron; therefore, it seems that the term citrangole may 
indicate other complexities. In fact, according to J. Brunet and O. Redon, ${ }^{15}$ this term refers to sour oranges, which seems to confirm the illumination of the Grandes heures d'Anne de Bretagne ${ }^{16}$ where a margin of the manuscript refers to "citrangulus" (orange fruits) suspended from a thorny branch.

The diversity of these terms is less important in Spain where naranjas are designated oranges used in cooking. However, in 1450, Roberto de Nola differentiates "naranjas" from "naranjas agras" and specifies it in a stew entitled Celiandrate ${ }^{17}$ with a "naranjas agras" base and a sweet, white grape juice, which curbs "the acidity of the dish... [as] the sauce must be between acidic and sweet".

Whatever the term, it is certain that the oranges used in these recipes were always sour. In fact, Nostradamus ${ }^{18}$ states that in his recipe Confire l'orangeat it is necessary to let the preparation set so that it will be "better and softer, because the natural bitterness of oranges softens with time thanks to the sugar or honey". In fact, sweet oranges were introduced very late, in the 1480 s, as was first attested in Italy by S. Tolkowsky. ${ }^{19}$

In Italy and Spain, on the other hand, lemons are designated under the terms of limoni or limoncelli, terms coming from the Arabic term laymun. Italian culinary treatises also used " lumie", "lomie" or "limia", referring probably to limes, whose pulp is less bitter than that of the lemon. Is it this fruit that Nostradamus refers to in his recipe Confire des oranges ou des écorces de limons au sucre in which it is necessary to "proceed in the way that I have just to explained for lemons". ${ }^{20}$

The difficulty in precisely naming a fruit is, for example, met in Le Ménagier de Paris, with the word "chitron". Does this term, which designates a candied fruit, refer to a citron ( Citrus medica) or a derived species such as lemon or lime? ${ }^{21}$

In other written sources, such as those referring to imported products, there are hints on the trade of these foodstuffs; indeed, citrus fruits are mentioned among the lists of taxed goods (leudes or leudaires). These lists indicate the amount of money (leude) received on the goods traded in a commercial marketplace. At first the amount taxed on a certain quantity of products became, during the course of the $13^{\text {th }}$ century, the amount taxed on each single product. The tax fees took on the form of a list of goods taxed individually, according to their type, treatment, geographical and seller's origin, as well as their quantity, volume and weight. ${ }^{22}$ These tax lists were used as models from one city to the next. ${ }^{23}$ Unfortunately, this reference is not comprehensive because only the taxed products were listed. In this paper, the written sources concern the eastern Iberian Peninsula (from Narbonne to Valence), from the Mediterranean coast to inland (Cerdagne), and several references outside of these borders. Seaboard and land trade taxes were taken into account. The tax list of Narbonne was the oldest document studied; the text is dated to 1153 , but our copy was made much later, and it is therefore necessary to consider it with precaution..$^{24}$ Among the Catalan tax lists we consulted, the Barcelona one dated to 1222 is the oldest. ${ }^{25}$ What makes this document interesting is that it mentions local fruit tree production, which the other texts do not.

\subsection{Iconographical sources}

13 Medieval drawings concerning the growing and harvesting of fruits and vegetables, ${ }^{26}$ as well as those containing the transformed culinary product, or meal rituals, are plentiful. Besides the calendars, which depict the peasant's work from one month to the next, the 
fruits are shown in numerous miniatures. Often they accompany biblical texts, but they are mainly found in scientific books, in particular those concerning agricultural treatises. Furthermore, herbariums and health treatises show a particular interest in fruit trees. Among these documents, the most famous is the Tacuinum sanitatis, a Latin translation of a text from the $11^{\text {th }}$ century by a Christian doctor from Baghdad, Ibn Butlan, which contains numerous sections concerning those fruits and vegetables which promote good health. Many versions were illustrated in northern Italy in the $14^{\text {th }}$ and $15^{\text {th }}$ centuries. Furthermore, these fruits and vegetables were sometimes found in religious ceremonial and secular meals.

Nevertheless, one must remain cautious when using these iconographical sources as certain factors limit the value of the corpus documents we used. Until the $13^{\text {th }}$ century, illustrations were not very realistic; an illustration was essentially symbolic, for the glory of God. The awakening of naturalism became more and more perceptible during the $14^{\text {th }}$ and $15^{\text {th }}$ centuries, but even in herbariums. "It is not always easy to determine with certainty the species represented". ${ }^{27}$

As a preliminary conclusion, illustrated encyclopaedias and herbariums gave more or less exact knowledge on the existence and description of plants for scholars, botanists and doctors. Agronomical treatises, illustrated cultivation scenes in the Books of Hours, on calendars and tacuins inform us of their cultivation in the country of origin of the author, or of their exotic nature and where and how they were grown. Trade tax lists document their geographical origin and the commercial value of the fresh fruit or the transformed version, as in the case of citrus fruit. As for the culinary treatises, they inform as to how the fruits were consumed, their culinary role and the social status of their consumers.

\subsection{Archaeobotanical evidence}

As is the case for most fruit remains, they are generally found in cesspits, latrines, sewers or abandoned wells which were used as rubbish disposals or places where domestic waste accumulated. Pollen grains, leaves and seeds, but also pieces of fruit (pericarp or rind) ${ }^{28}$ from citron, lemon and sour orange were discovered at several different archaeological sites, covering different periods of time, in the eastern Mediterranean and Europe. The macroremains were preserved either in a waterlogged, mineralized, sub-fossilized state (seeds) or in a desiccated state (leaves and fruit). ${ }^{29}$ In the case of the Citrus genus, precise botanical identifications are based on anatomical and morphological seed criteria, which are not always applicable for archaeological seeds due to the disappearance of diagnostic features (eroded surface of the tegument, seed deformation). ${ }^{30}$ In France, before the discovery at Bordeaux, no Citrus remains were documented due to the rarity of organic matter preserved under constant anaerobic conditions. Even if waste pits or latrines were frequently used in urban areas, the layers were often subjects to progressive drying during burying. Plant remains are usually preserved by mineralization and not easily identifiable for certain groups; therefore, it is highly probable that the mineralized citrus seeds discovered were simply not differentiated from other seeds. In any case, it seems that the eating habits and limited access to these fruits, which were reserved for the more wealthy families, are also some of the reasons for the low records of this species in the archaeobotanical spectra. Archaeobotanical discoveries allow us to document use contexts that are different from those of written documents and drawings. Through the 
consumption of fruit, researchers can follow their expansion within a geographical area and over a specific period of time.

\section{Citrus fruit through the illustrations and texts of medieval Europe}

17 Following the Greco-Roman written documents for the antique Mediterranean, the oldest written European medieval traces of citrus fruit trees are found in the treatises of the Arab-Andalousian agronomical school from the $10^{\text {th }}$ century onward. They show that the citron fruit tree (Citrus medica) was introduced and had been cultivated in the Iberian Peninsula since at least the $7^{\text {th }}$ century, at the time of the Arab conquest; the sour orange tree (C. $x$ aurantium) since the $10^{\text {th }}$ century, and the lemon tree (C. $x$ limon) since the $10^{\text {th }}$ or $11^{\text {th }}$ centuries. ${ }^{31}$ From the $12^{\text {th }}-13^{\text {th }}$ centuries, the contents of the tax lists show that citrus fruits were sold to more northern areas, in particular France. Their integration into the aristocratic culinary dishes of temperate Europe is recorded in the culinary treatises of the $13^{\text {th }}-15^{\text {th }}$ centuries.

\subsection{Citrus fruit knowledge and representation}

Medieval iconographical documents where citrus fruits are represented reached the West very late. Moreover, for a long time artists were very imprecise when it came to illustrating their works. The oldest drawings are from medicinal plant reference books, for medical use or in health treatises. These works do not allow the naming of the species represented and as G. Comet ${ }^{32}$ stated "the image does not really help unless it is named".

19 A few copies of the Livre des simples médecines contain a section on the lemon. This particular work is, in fact, composed of numerous illustrated herbariums whose origins go back to classical Roman antiquity, and were constantly updated until Matthaeus Platearius wrote his $13^{\text {th }}$ century treatise entitled De simplici medicina or Circa Instans. ${ }^{33}$ Besides animals and minerals, 229 plants are identified among the 273 items $^{34}$ of this dictionary which deals with therapeutic treatments as well as the positive and negative effects of drug use. Around the year 1300, many translations into French were made which reveal that this book was not only appreciated by doctors but also by surgeons, apothecaries and herbalists. However, it was only, in the $15^{\text {th }}$ century that illuminated copies started increasing. The stylistic differences between the numerous copies are noticeable ${ }^{35}$ and each section is often decorated with a miniature which covers the width of about one or two columns of text.

Among the illustrated plants, some were somewhat realistically drawn, whereas others were drawn in a more unrealistic fashion, or in the case of the lemon, appear to have been unfamiliar to the illustrator himself. Devoid of a botanical reference, deformed or reinterpreted by the copyists through the years "they are derived from primitive-type images, which were themselves copied from earlier herbaria or drawn from memory" ${ }^{36}$ rendering these plants almost so unrecognizable as to be merely abstracts. ${ }^{37}$

21 Like herbaceous plants, trees are represented in their entirety with their bare roots, but among the different copies two models are adopted to represent the lemon tree: sometimes it is shown as a bush with branches radiating from the base, like an illuminated version in Burgundy in $1452,{ }^{38}$ sometimes as a tree with a slender trunk 
crowned with a bouquet of long-leaved branches whose ends are rounded, as in some copies from western France. ${ }^{39}$

For the lemon tree, as was the case for many foreign tree species, the artists attempted to distinguish the species through their fruit, without being very realistic. Indeed in some of the copies, the fruit hanging from the trees are yellow, ${ }^{40}$ but they can also be brown ${ }^{41}$ or orange ${ }^{42}$ and sometimes they are both brown and yellow on the same tree. ${ }^{43}$ The shape of the fruit were also approximately drawn as seen in a French version of the Livre des simples médecines from the second half of the $15^{\text {th }}$ century: on the same folio a chestnut tree and a lemon tree are drawn; their port and their foliage are similar and their fruits consist of small identical balls, the former green and the latter brown. ${ }^{44}$

It is worth noting that in a few copies of the book, lemons are not designated under the name citra, but rather "citrules" which means pickle. As P. Lieutaghi explains, ${ }^{45}$ this classification may have been due to a phonetic confusion between these two plants, unless an unfortunate association was made because of the lemon-yellow citrine colour of these two fruits.

As for the orange, it was rarely present in medical books during the Middle Ages, since it was thought to have only a few therapeutic qualities. However, in the Libro de componere herbe et fructi by Giovanni Cadamosto da Lodi, illuminated in the north of Italy in around $1471{ }^{46}$ an orange and a lemon tree - which are perfectly identical except for the colour of the fruits which are either yellow or orange, according to the species - are drawn on the same folio. As for the citron, a Compendium salernitatum (medical treatise) illuminated in Venice three quarters into the $14^{\text {th }}$ century ${ }^{47}$ includes it under the name of "limon" which refers to the lemon tree in culinary texts: the tree is shown with long leaves and elongated, bumpy yellow fruit which resemble, to a certain extent, the features of the fruits. Herbariums were not the only "scientific" books to mention citrus fruit; health treatises also advised the eating of fruit, in particular, oranges or lemons. The most famous work among them, the Tacuinum sanitatis, by Ibn Butlan, lists 280 exotic species new to the west, such as the banana, the date and even the pomegranate. This work became quite famous in Italy in the $14^{\text {th }}$ and $15^{\text {th }}$ centuries with nine ${ }^{48}$ out of eleven Latin copies being splendidly illuminated, starting in 1370 , by northern Italian artists, in particular the Lombards. Even though an initial copy by Giovaninno de' Grassi ${ }^{49} \mathrm{did}$ not include a section on citrus fruit, three or four sections were later devoted to them in an illuminated version of his work written between 1390 and 1400 in Pavie or Milan. ${ }^{50}$ In this later work the "citra" (without a doubt, citrons), "51 "citroni" (bitter oranges), ${ }^{52}$ "limoni" (lemons), ${ }^{53}$ and a fourth section, devoted to the sweet-smelling citron: "de hodoriferis citris ${ }^{{ }^{5} 4}$ are illustrated.

In all the different versions of the Tacuinum, the orange and lemon trees are always shown with a slender trunk topped with a spherical bouquet of branches and elongated leaves. On the other hand, the citron trees are either drawn as trees, resembling other citrus fruit trees, or as bushes with many branches which radiate out from the roots. This is the same for the herbariums: both the orange ${ }^{55}$ and the lemon tree ${ }^{56}$ are represented as balls; it is only their colour of their fruit which differentiates them. Citrons, also called " nabach id est cedrum" or "zitronen" ${ }^{57}$ are differentiated by their imposing size, which in certain copies exceeds $30 \mathrm{~cm}$, but mainly by the texture of their rough, granular, dented and bumpy fruit which makes them resemble bunches of white grapes. ${ }^{58}$ introduction of flowers, fruits or insects increased in the margins of other manuscripts. 
These increasingly realistic drawings enable us to precisely determine the species more frequently. One of the most famous examples is that of the Grandes heures d'Anne de Bretagne, ${ }^{59}$ illuminated between 1503 and 1508 by Jean Bourdichon from Tours, which depicts orange coloured fruit suspended from the prickly branch of a sour orange tree, as confirmed by the associated inscription of "citrangulus". ${ }^{60}$ These framed compositions of strings of plants were particularly fashionable in Italian sculpture at the time. During the 1460s, Lucca della Robbia, from Florence, and his workshop apprentices sculpted many realistically coloured friezes of Renaissance majolica where fruits, vegetables and other plant elements intertwine. Thus plums, quinces, cucumbers, lemons and pine cones enlace Saint Mary Magdalene, ${ }^{61}$ while flowers, plums, quinces, oranges or citrons, pomegranates, aubergines and pickles encircle Saint John the Baptist. ${ }^{62}$ In these compositions, the lemons and oranges are quite realistically represented using the colour yellow, but also in the rough texture of the peel and the characteristically contoured leaves protruding from the top of the fruit, which indicates the illustrator's first-hand knowledge of the fruit.

\subsection{Places, growing methods and diffusion}

The cultivation of some citrus fruit species since Greek and Roman antiquity, especially the citron (Citrus medica), and the lemon tree (Citrus xlemon), in the eastern Mediterranean - Carthage, Rome, Pompeii and Cumae for example - is subsequently confirmed by both Latin and Greek texts or by the archaeobotanical remains. ${ }^{63}$

Indeed, recorded pollen discoveries in the antique sediment layers show that trees existed in these areas, raising questions on plant acclimation and growing conditions in order to produce fruit. Though Theophrastus explicitly explained how to grow a citrus tree, one does wonder if the cultivation of this "exotic" species in an urban environment was not simply for ostentatious reasons. ${ }^{64}$

The only lime fruit and seed remains, (Citrus $x$ aurantiifolia) dated by radiocarbon to the 11 th $-12^{\text {th }}$ centuries, have been found at the Egyptian site of Quseir al-Quadim. In this harbour zone an active seaborne trade existed, with many products being imported from countries bordering the Indian Ocean ${ }^{65}$ Indeed, mentions of the first cultivations in Spain come from Arab-Andalousian writers. The citron tree and the sour orange, introduced between the $7^{\text {th }}$ and $11^{\text {th }}$ centuries, spread further north in the $13^{\text {th }}$ century around the northern Iberian Peninsula in Aragon and later in Catalonia. ${ }^{66}$ By the $11^{\text {th }}$ century the grapefruit tree (C. maxima), called the "zamboa" 67 in the Livre de l'Agriculture of Ibn al'Awwâm (12 $2^{\text {th }}$ century), was being cultivated in Al-Andalus, whereas limes (C. aurantifolia ) were not introduced until the $14^{\text {th }}$ century. ${ }^{68}$ Based on what Abû al-Khaïr the agronomist said in the $11^{\text {th }}$ century, Ibn al'Awwâm considered that the cultivation of the citron tree, the sour orange tree, the lemon tree and the grapefruit tree were comparable to these related species. ${ }^{69}$ Furthermore, he listed the cultivation techniques for these fruit trees according to various Arabic and antique sources: they are planted into the ground after being transplanted from cutting and layering or from seedlings; watering and the use of manure (sheep dung, horse dung dust, decayed human faeces) are necessary; the season during which the cuttings are planted vary according to who cultivated them and what species was cultivated: either in autumn (September) or spring (March, April), but the sour orange tree must be planted in January; cuttings and layers are planted directly into the ground and seedlings are put into big earthenware pots. Grafting was only mentioned 
for the grapefruit tree, and only that it should be carried out with and on the same tree. For the sour orange, Ibn al'Awwâm gives details for nursery seedling transplanting and how to care for plants (watering, hoeing).

Some varieties of the citron trees, sour orange trees and lemon trees he described must have been cultivated in Spain since at least the $10^{\text {th }}-11^{\text {th }}$ century. The diffusion to the north of these fragile and demanding crops, which required much heat and humidity, took place rather slowly with the first mentions in southern France dating back to only the $15^{\text {th }}$ century: orange trees are reported in a garden in Aix-en-Provence in $1427 .^{70}$ While travelling across Europe at the end of the $15^{\text {th }}$ century, Dr Hieronymus Münzer (1494-95) described the garden of his host in the city of Perpignan: here are planted tree species; some are pomegranate trees, orange trees, fig trees, almond trees, peach trees, medlar trees, grapevines and numerous other fruit trees. ${ }^{71}$

31 Citrus trees were also cultivated in the orangeries of big castles and Bohemian courts, during the Middle Ages. A copy of the Manuel des vertus des animaux et des végétaux, ${ }^{72}$ inspired by Tacuina and illuminated in Venice in around 1480, shows that for the citrona et naratia sections, fruit trees with yellow fruits - without a doubt lemons - were planted in wooden boxes; a practice which shows that the plants were probably transferred indoors during the winter for their protection. ${ }^{73}$ These new fruit trees, from a horticultural heritage, were reproduced on a small scale at aristocratic and royal estates, and remained exotic curiosities in the northern latitudes such as Flanders and northern France. In the $17^{\text {th }}$ and $18^{\text {th }}$ centuries in temperate Europe, citrus fruit and other exotic fruits, kept in orangeries and in heated glasshouses would continue to be the privilege of a scholarly horticultural heritage at the service of the customs and gastronomical tastes of nobles and the newly rich.

\subsection{Ways of consuming citrus fruit}

In the medieval west, the integration of fruit in cooking, at least according to the aristocratic culinary treatises which documented the habits and tastes of the time, varied from one geographical area to another. ${ }^{74}$ Oranges and lemons were appreciated for their acidity, but they were only rarely mentioned in the treatises. They are absent from German $^{75}$ and English ${ }^{76}$ recipes and were only rarely mentioned in most French culinary books: for example, we did not find any reference to their use in the $14^{\text {th }}$ century either in the Enseingnemenz qui enseingnent a apareillier toutes manières de viandes ${ }^{77}$, or in the Viandier de Sion. ${ }^{78}$ In the $15^{\text {th }}$ century, they are also left out of such southern treatises as Du fait de cuisine by Maitre Chiquart, written in 1420 in Savoy for Amadeus VIII or in the Recueil de Riom et la manière de henter soutillement written around 1466 by a bourgeois from the Forez region of France. ${ }^{79}$ As for the Vivendier, ${ }^{80}$ without a doubt written in Flanders between 1420 and 1440, oranges are only mentioned in one recipe Pour cuire un poisson de trois manières et de [trois] couleurs. In the Ménagier de Paris, ${ }^{81}$ composed around 1392, by a rich bourgeois from Paris - who was much older than his young inexperienced spouse - there were no recipes containing lemon and only five out of the 280 recipes used oranges. These mostly used the juice of the fruit to mix with wine as a sauce for partridges, chicks, capons or even fish, such as mullet; ${ }^{82}$ the name of this recipe is Mulet est dit mungon en Languedoc. ${ }^{83}$

33 Although citrus fruits are rarely mentioned in northern records, they are often mentioned in the southern culinary books. This realisation is hardly surprising 
considering that the pronounced sweet and sour Mediterranean flavour is shared by Italy, Languedoc and Catalonia. ${ }^{84}$ However, in Languedoc only one out of the 51 recipes of the Modus viaticorum preparandorum et salsarum ${ }^{85}$ written in a mix of Latin and Occitan undoubtedly in eastern Languedoc between 1380 and 1390, uses lemon juice limonieyra blanca $^{86}$ (or verjuice, if lemon was not available) in a chicken preparation. This treatise does not mention the use of oranges.

In Italy, since the beginning of the $14^{\text {th }}$ century in the Liber de coquina, commissioned by the House of Anjou-Sicily and elaborated in southern Italy, $12 \%$ of the recipes contain either orange or lemon juice. If citrus fruits are hardly mentioned in the Venetian Libro per cuoco, ${ }^{87}$ partially written around 1338 (2.2\% of the recipes), one finds a significant percentage (12\%), in the Libro della cocina, a Tuscan document from the end of the $14^{\text {th }}$ century. This taste for citrus fruit is not lost at the end of the Middle Ages as confirmed in the Libro de arte coquinaria, compiled by Maestro Martino de Rossi between 1456 and 1467 , where one can find 22 , out of 270 , recipes which contain oranges or lemons (i.e. $8.14 \%$ of the preparations).

However, it is in Catalonia where the use of lemons and oranges are the most extensively documented. Although in the Llibre de Sent Sovi, written around 1324 in Catalonia, ${ }^{88}$ there are 11 , out of 222 , recipes which include citrus fruit (i.e. $4 \%$ of the recipes). This proportion becomes much bigger in the Libre del coch ${ }^{89}$ written around 1477 in Catalan by Mestre Robert, also known as Ruperto de Nola (or Roberto de Nola), where, 39, out of 236, recipes are based on citrus fruit (i.e.16.5\%). It must not be forgotten that Nola had been the chef to Ferdinand I, King of Naples, from 1458 to $1494,{ }^{90}$ and that his recipes are indicative of the crossover between Catalan and Italian culinary practices. ${ }^{91}$ The integration of citrus fruit in cooking is so characteristic of the Catalan region that the Italian Master Martino de' Rossi decided to call his pomegranate or lemon juice partridge dish "à la mode catalane". ${ }^{92}$ Moreover, in the Catalan document the Sent Sovi ${ }^{93}$ and in a few Italian records, including those of Martino, sour orange juice ("sucho di pomaranci") is used to make a sauce to accompany fried or boiled fish. Furthermore, the Libro della cucina served roast goose with a "succo d'aranci o di limoncelli o di lumie" (undoubtedly lime). ${ }^{94}$ It appears that this acidic substance was often chosen by the chef to prepare the recipe Charbonnée de porc, where Martino suggests replacing the vinegar with "... del sucho d'aranci, o limoni, ...". ${ }^{95}$ In 1339, the Tuscan chef wrote ${ }^{96}$ that a dish based on arancia must be sour: "questa vivanda vuol essere... agra d'aranci".

Besides the juice, the peel and pulp of the oranges were also consumed candied. In fact, they became the essential ingredient of a soft drink called "orangeat". The author of the Ménagier de Paris mentions "chitron" on his grocery list of purchases for wedding banquets, which are found under the heading of "épices de chambre" bought at the local grocery store. ${ }^{97}$ Perhaps this refers to candied lemons.

\subsection{Provision of citrus fruit}

Although rarely cited in commercial documents, the citrus fruits imported into -

Roussillon from Al-Andalus are cited in the tax list (leudes) of Collioure, southern France, in the $13^{\text {th }}$ and $14^{\text {th }}$ centuries. It probably concerns goods that had been recently introduced to the Roussillon markets because the tax list (leude) which included citrus fruit ends with the sentence "they are neither named nor known to the leuders and their worth 
is only relative to the value of previous products". It seems "that some officers do not know how to name these goods" lemons (limons) and oranges (terongers). But does the term "pomers" refer to grapefruit? The cultivation of this fruit is reported in the Livre d'Agriculture of the $12^{\text {th }}$ century by Ibn al'Awwâm and could be included among the market goods of Collioure. Nevertheless, the citron, the mandarin or bergamot fruits could have circulated in the Mediterranean Basin at this time, as the trade of these fruits was developing in the middle of the $13^{\text {th }}$ century in the countries of the Kingdom of Aragon.

It is interesting to note that in Paris at the end of the $14^{\text {th }}$ century, according to the author of the culinary treatise the Ménagier de Paris, oranges were bought fresh at markets just like pomegranates, sorrel, cheese, eggs and even salt. Further north, according to domestic accounts, citrus fruits were being exported to England, ${ }^{99}$ with customs documents containing several entries of oranges but no lemons. One text for London in 1420 listed three cargoes containing oranges; after 1509 it lists only one cargo of oranges and cork. ${ }^{100}$

\subsection{Citrus fruit and symbolic meaning}

Like many other symbolically loaded fruits and trees, oranges and lemons were used quite extensively in medieval iconography, some secular but primarily religious. ${ }^{101}$ In this way, orange tree fruits and flowers became a symbol of purity and virginity, and is therefore often associated with the Virgin Mary. In Italy, it is common to find an orange tree planted next to a statue of the Madonna or in the background of a painting representing the Virgin Mary surrounded by saints. An orange tree is drawn in the background of Madonna dell'Arancio surrounded by Saint-Louis of Toulouse and Saint Jerome, painted by Giovanni Battista Cima da Conegliano around 1496-1498. ${ }^{102}$ In Madonna con Bambino in un giardino, a work by Cosmé Tura, painted around $1460-70,{ }^{103}$ the seat of the throne of the Virgin is surrounded by orange trees. In the Madonna col Bambino e un angelo, ${ }^{104}$ painted by Giovanni Agostino da Lodi in the beginning of the $16^{\text {th }}$ century, besides the oranges which make up the painting's background, an angel is offering an orange to baby Jesus. In close symbolic resemblance, the lemon tree is sometimes associated with the orange tree. In the Trivulzio Madonna painted in 1497 by Mantegna, the enthroned Madonna is surrounded by Saint John the Baptist, Saint Jerome, Saint Gregory the Great and Saint Benedict. The saints are surmounted by two citrus trees ${ }^{105}$ or as in the San Zeno Altarpiece showing the Madonna surrounded by chanting angels and lemon and orange garlands surmounting above the figures. ${ }^{106}$

Oranges and lemons are also symbols of salvation. In a certain number of Flemish paintings at the end of the $15^{\text {th }}$ century, baby Jesus, in the arms of his mother, is holding an orange instead of the traditional apple. More often still the fruit is depicted cut and placed on a little table in the foreground, for example in the Holy Family by Joos Van Cleve, painted around 1464-1540; next to the citrus fruit another symbol of Christ, the grape, is also placed. ${ }^{107}$ In these paintings, the orange can also be placed with the pomegranate ${ }^{108}$ or with cherries: fruits which incarnate the Passion of Christ. ${ }^{109}$ It is true that other than the association with the Redemption, the Dutch term (Sinaasappel), which designates the orange, means Chinese apple. Just as often, it is the lemon which symbolizes salvation, as in the paintings of the Virgin and Child produced in the Netherlands at the end of the Middle Ages. It is also said to have healing properties, 
particularly against poison. In these paintings the orange and lemon are placed cut in half, and next to them the painter frequently displays a slice of the fruit with the seeds and knife in sight, as in the Madonna and Child Nursing, painted around 1500 by an anonymous Flemish school master. ${ }^{110}$ This symbolic association between the lemon and redemption can also be integrated in other religious themes as in Cenacolo di Ognissanti, painted in the dining hall of the San Marco Basilica convent, Florence, around 1480 by Domenico Ghirlandaio, where lemon and citron trees are figuratively drawn in the background landscape. It is also a lemon tree which is associated with the host in the Miracle of the Profaned Host painted by Uccello around 1465: next to the tree, which is adorned with many yellow fruits, two angels and two devils are fighting over the body of a woman in front of the altar. ${ }^{111}$

At the end of the Middle Ages, when lemons and oranges become more common, they were more often used decoratively and are integrated in many profane scenes. If we are not surprised at finding sliced oranges decorating a Hispano-Moorish ceramic platter, painted in Spain in the middle of the $15^{\text {th }}$ century, ${ }^{112}$ we should not be surprised to see sculptures of orange, lemon and date trees on the main building of Jacques Coeur's palace, Bourges, from around 1450; a feature which strongly expressed the prosperous business which was developing with eastern countries. Moreover, the orange tree symbolized Jacques Coeur's wife, as it bears flowers as well as fruits which is a sign of femininity.

Not only were they portrayed as positive symbols, citrus fruits were sometimes used as a highly precious currency at the end of the Middle Ages. ${ }^{113}$ Thus, in the Duke de Berry's inventories, the coat of arms is suspended from the branches of orange trees. ${ }^{114}$ In the same way, Jeanne de Laval, the second wife of René d'Anjou, adopted the language of symbolism. In his honour she had oranges trees painted on the walls of his manor, HauteFolie. By around 1460, hackberry, pine and orange trees were being used to decorate the chapel vaults of the manor of the then King René in La Ménitré, alternately supporting his coat of arms and Jeanne de Laval's; whereas in Rivettes, it is only on the chapel wall where the orange trees of Jeanne de Laval's arms appear. ${ }^{115}$ Finally, at the beginning of the $16^{\text {th }}$ century, the orange becomes sufficiently well known to be integrated in the French manuscript the Rébus de Picardie. The beginning of the maxim "Or en pensée, or en joie, Quand je tiens d'amour la voie" is transcribed on two illuminated copies ${ }^{116}$ by a schematic flower, a pansy, whose heart is a gold dot, then, by a simple sphere recalling the orange. As J. Céard and J.-C. Margolin ${ }^{117}$ noted, a gold dot next to an orange "is an ingenious comparison since it represented orange as gold", whereas oranges "are called aurentian quasi aurea mala because they are the colour of gold". ${ }^{118}$

\section{Archaeobotannical evidence of citrus fruit in France}

Even though a few archaeobotanical discoveries on antique sites provide some knowledge on the consumption of citrus fruits, such as the citron and the lemon in Italy, ${ }^{119}$ no citrus fruit remains have yet been recorded from medieval western European sites. The first documented archaeobotanical references in this area date back to the modern period. 


\subsection{In Modern Europe}

44 Some seeds, identified as being of the genus Citrus appear between the $16^{\text {th }}$ and the $18^{\text {th }}$ centuries in urban latrines, cesspits and waste pits in the Netherlands, ${ }^{120}$ Germany and the Czech Republic. Sweet orange (Citrus sinensis) and mandarin seeds (Citrus cf. reticulata) respectively, were extracted from the floor of a vault in the Vladislav Hall, Prague Castle, 121 and sour orange leaves were recovered from the funeral wreath of Archduchess Eleanor of the Habsburg family, buried in $1580^{122}$ (tab. 1). This constitutes the first direct evidence of the funerary use of this species north of the Alps. In Germany, the only published archaeobotanical data are those of the remains of sweet orange or mandarin ( Citrus sinensis/C reticulata), dating back to the $17^{\text {th }}$ and $19^{\text {th }}$ centuries, and one desiccated pummelo or grapefruit seed (Citrus maxima/C. $\mathrm{x}$ paradisi) found in a wooden floor of the same period. ${ }^{123}$

Tab. 1 - Records of Citrus spp. archaeobotanical remains in European sites except the Netherlands (for Dutch sites see W. Van der Meer in this book).

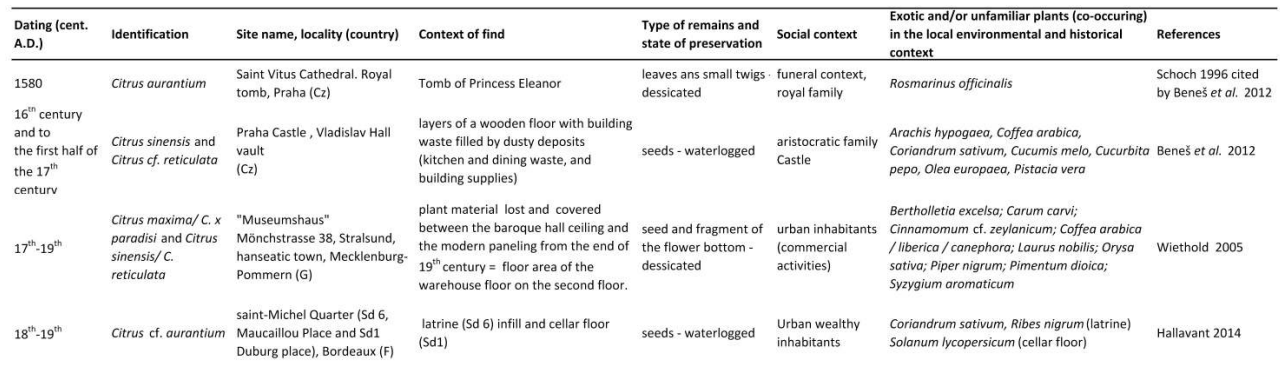

These infrequent archaeobotanical discoveries suggest that citrus remained rare in Europe. This rarity is a little surprising since the fruit contains numerous seeds which are robust enough to be preserved.

\subsection{The first evidence in France}

In France, the discovery of five waterlogged seeds in a modern fill of a cesspit at the "Espace Saint-Michel" site in Bordeaux (Gironde department) is the only carpological occurrence known to this day.

\subsubsection{Archaeological context}


Fig. 1 - Location of the archaeological site: a. Location of the town of Bordeaux in southern France; b. Topographical map showing the location of the excavated site of Saint-Michel near the Garonne river.

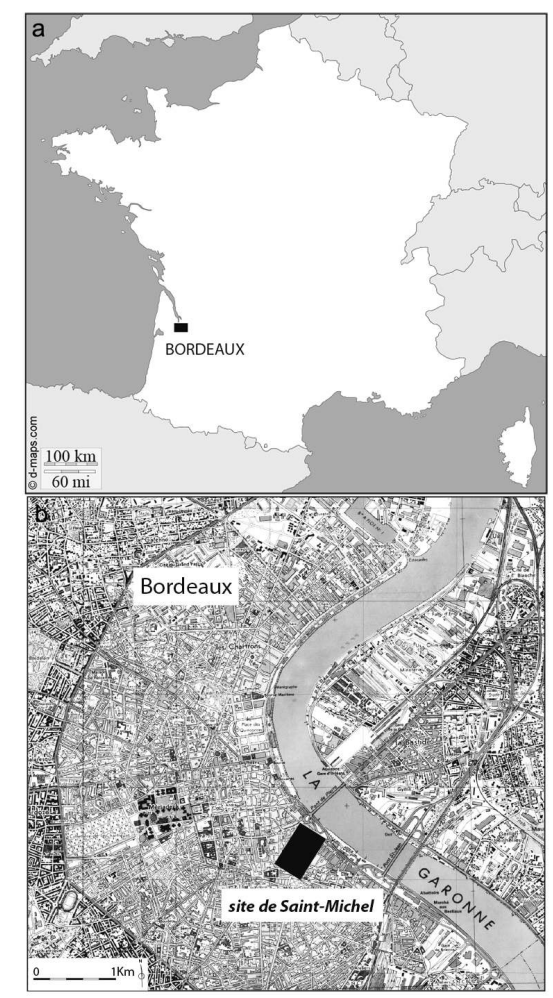

Prior to modernisation of the Saint-Michel quarter (June 2011-May 2015) on the left bank of the centre of Bordeaux (fig. 1a-b), INRAP archaeologists had the opportunity to excavate, which allowed them to obtain information on the evolution of this quarter, including its buildings, road networks and its medieval cemetery. Six archaeological test pits were opened (fig. 2a), three of which were excavated (sd. 1, 3 and 6) to a surface area of about $300 \mathrm{~m} .{ }^{124}$ For this study, we will concentrate on the excavation of test pit 6 (sd. 6), situated on today's Maucaillou Place some $400 \mathrm{~m}$ south-west of Saint-Michel's church. Two set of buildings were distinguished and the successive rebuilding, stretching over four centuries, provides evidence of the creation of cellars and the installation of latrines which were demolished only at the end of the $19^{\text {th }}$ century during renovation of the quarter. 
Fig. 2 - Archaeological context of the Citrus remain findings: a. Location of the six archaeological soundings (Sd. 1-6). The investigated latrine located on the sd. 6 in Maucaillou Place; b. Latrine $6.1 ;$ c. Stratigraphic profile of the fill of latrine 6.1.
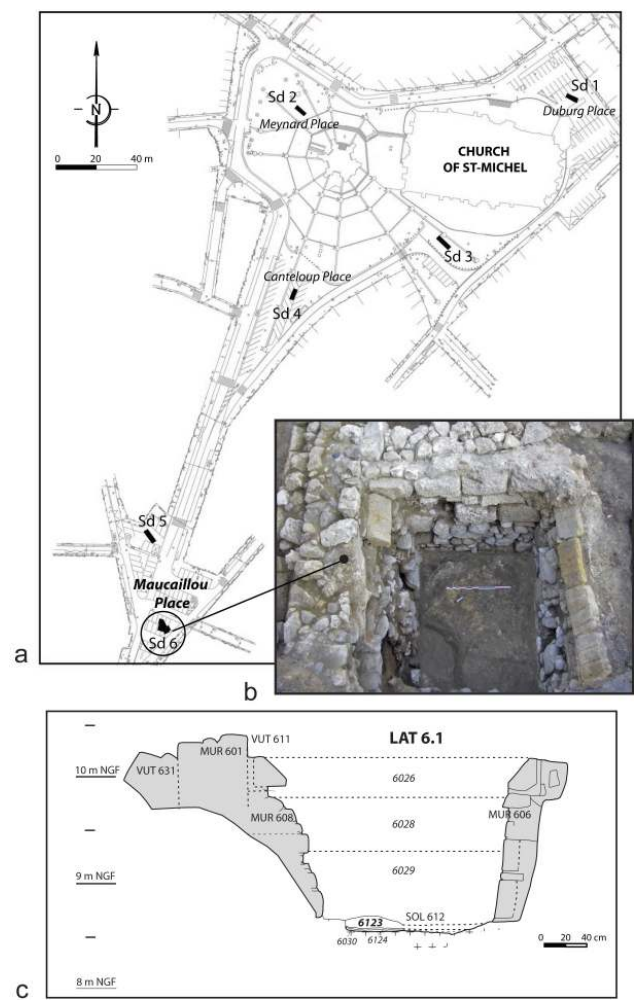

a: Map CUB, topographical plan and drawing C. Proye-Guimard and N. Sauvaître Hadès 2013, modified by C. Hallavant Hadès 2016; b: Photograph D. Delage Hadès 2011; c: Drawing and DAC F. Larre,

D. Delage and L. Maccanin Hadès 2012, modified by C. Hallavant Hadès 2016.

The first building had been converted into a cellar with three basement windows in the 18 th century; in the $19^{\text {th }}$ century it was furnished with a cesspit. The second building was equipped with a stone outhouse, set back from the street. The latter (LAT. 6.1) was subject to a careful search in a bid to understand how it had been constructed, and what the organic levels were composed of (fig. 2b). Built around the first half of the $18^{\text {th }}$ century, this construction, buried about $7 \mathrm{~m}^{3}$ underground, was covered by a vault (triangularsized sculpted stones), and had been made waterproof thanks to the lime-based coating that covered the stones. The dimensions suggest it was created for the common use of different occupants (the overall length measured $2.2 \mathrm{~m}$, the width $2 \mathrm{~m}$, and the empty structure depth measured $1.58 \mathrm{~m}$ ). The fill was mechanically extracted, which exposed three undisturbed layers (fig. 2c): a thin layer of dark loam with a very organic appearance (US 6030), a very fine layer of white lime mortar (US 6124) and a thicker layer of dark-brown wet and clayey loam containing unrecognizable coins, some metallic objects, a few fauna fragments and a large quantity of seeds (US 6123).

\subsubsection{Carpological data}

A sample of 5 litres was removed from US 6123. It was wet sieved by flotation using mesh sizes of 2 and $0.5 \mathrm{~mm}$. After sieving, the residue, which was not dried to preserve the waterlogged seeds, was sorted using a stereomicroscope with $6 \mathrm{x}$ to $30 \mathrm{x}$ magnification. The total number of remains extracted from the subsequent samples was estimated 
relative to the initial volume. Close to 20000 remains, from which 18086 individual seeds were identified (density of remains per litre of sediment=3617 individuals) (tab. 2). The moisture in the sediment preserved three quarters of the remains (or $88.5 \%$ of the minimum number of items: MNI). ${ }^{125}$ No carbonized remains were detected but the presence of mineralized remains, or those in the course of mineralization, was small (8.2\% MNI). Sixteen taxa were identified: lentils (Lens culinaris), broad beans (Vicia faba var . minor), oilseed rape (Brassica napus), coriander (Coriandrum sativum), two wild plants and ten fruit trees. In this last category, which represented $99.5 \%$ of the MNI, three taxa were singled out as having a high quantity of isolated remains: the strawberry plant (Fragaria vesca) and the fig tree (Ficus carica), which made up $80.7 \%$ of the fruit remains, and the grapevine (Vitis vinifera) with $18.3 \%$. To this undiversified classical fruit collection was added a fruit tree rarely identified in France, the black currant bush (Ribes nigrum), and one (or more) unidentified citrus fruit (Citrus sp.), unheard of before in France, which yielded five seeds.

Tab. 2 - Taxa identified from waterlogged $(W)$ and mineralized $(M)$ seed and fruit remains in latrine LAT.6.1 of Bordeaux. FG, number of fragment seeds; NR, number of whole remains (seed or fruit), MNI, minimal number of items (FGN/2 + RN).

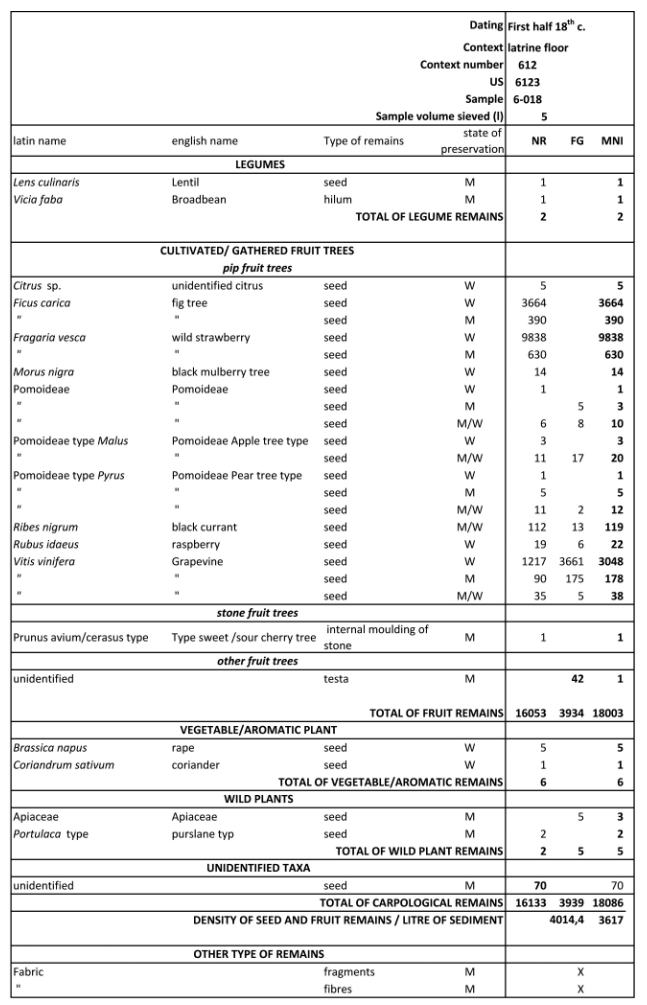

During this archaeological operation, other waterlogged contexts filled with domestic waste and faecal material caught our attention. Also in the same sector, a quadrangular pit, dated to the beginning of the $17^{\text {th }}$ century, supplied a range of plants which were nearly identical to those of US 6123 , with fruit trees making up $92 \%$ of the remains, in which the fig tree and grape pips (more than half of the remains) predominated. No rare or exotic plants were found. However, at Duburg Place, behind the church, (sd. 1; fig. 2a) the infill of the cellar floor (US 1296) provided no fewer than 46 tomato seeds (Solanum lycopersicum) mixed with a large quantity of fig and grape pips. In France, the tomato has 
never been identified in archaeobotanical remains, but unfortunately the large dating range ( $17^{\text {th }}$ to $19^{\text {th }}$ century) does not assure contemporaneity of the contexts.

\subsubsection{The population of the quarter at the end of the Middle Ages and during the Modern period. ${ }^{26}$}

In the Maucaillou quarter, a swamp during antiquity - especially the Saint-Michel quarter - many religious buildings were constructed (i.e. a convent and a hospital). These played a major role in the polarisation of the habitat and took advantage of this significant site within the vicinity of the Garonne river. Thus, at the end of the Middle Ages, the activities of the quarter seem centred on the zone used as a market place, linking the town to its harbour activities and river waterway traffic. Most of the population, from the rich merchants to the poorer artisans, lived off the river activities and the exchanges that took place there. However, although the quarter's reconstruction projects throughout the $18^{\text {th }}$ century (e.g. filling of ditches, reconstruction of the medieval gates) resulted in the creation of new aristocratic residences mixed with the modest housing of the former period, the population does not seem to have altered. The social categories mentioned in the archives of the modern period cited merchants and artisans but also aristocrats and lawyers, though this does not seem to have concerned the elite of the city, who were located further north. This quarter welcomed, therefore, an urban type of population rather than peasants, which was the case in other parishes where winegrowers were one of the biggest corporate bodies. Thus, coopers made up the largest part of the population, but the presence of sailors, trade seamen ("gabariers"), and ship builders reveal the influence of the Grave river embankments located near the SaintMichel church. This quarter opened onto two harboured areas, with French vessels moored close to the city, and further south those heading down the Garonne river. Maritime traffic was very active in the $18^{\text {th }}$ century; during the year 1714-1715, a total of 1713 moored ships (mostly from the Netherlands) and 50 from the Americas were listed.

\subsubsection{Description of the seeds of the "Espace Saint-Michel" site}

52 To identify the five seeds, we used the criteria published by Pagnoux et al.; ${ }^{127}$ views of the surfaces of teguments were captured by a portable JEOL electronic scanning microscope (SEM). ${ }^{128}$ The objects were placed on an adhesive backing without being metallized. Their cellular surface was analysed with 50x, 170x and 200x magnifications but comparisons were reliable at a magnification of at least 180x. Modern seeds of Citrus aurantium from the UMR 7209 seed reference collection were captured using the same methods, and were then compared with the archaeobotanical seeds. For the other Citrus species, we used images and descriptions published in Pagnoux et al. ${ }^{129}$

53 The shape of the two best-preserved seeds (fig. 3a-b) appeared quite variable: one is between fusiform and semi-deltoid shaped; the other one is ovoid. On the first one, the apex is prolonged with a curved beak and the radicle zone is elongated and lopsided (fig. 3c). On the second one, the apex is slightly elongated with a triangular and rounded shape. The radicle zone is rounded (fig. $3 \mathrm{~d}$ ). The two seeds have a pronounced ventral crest, but the base of the first ends in a peduncle and the second one is simply rounded. Their dimensions (length $\times$ breadth $\times$ width) are: $104 \times 37 \times 39$ and $89 \times 33 \times 41 \mathrm{~mm}$, respectively (fig. 4). 
Fig. 3 - Two waterlogged seeds of Citrus sp. from Bordeaux.

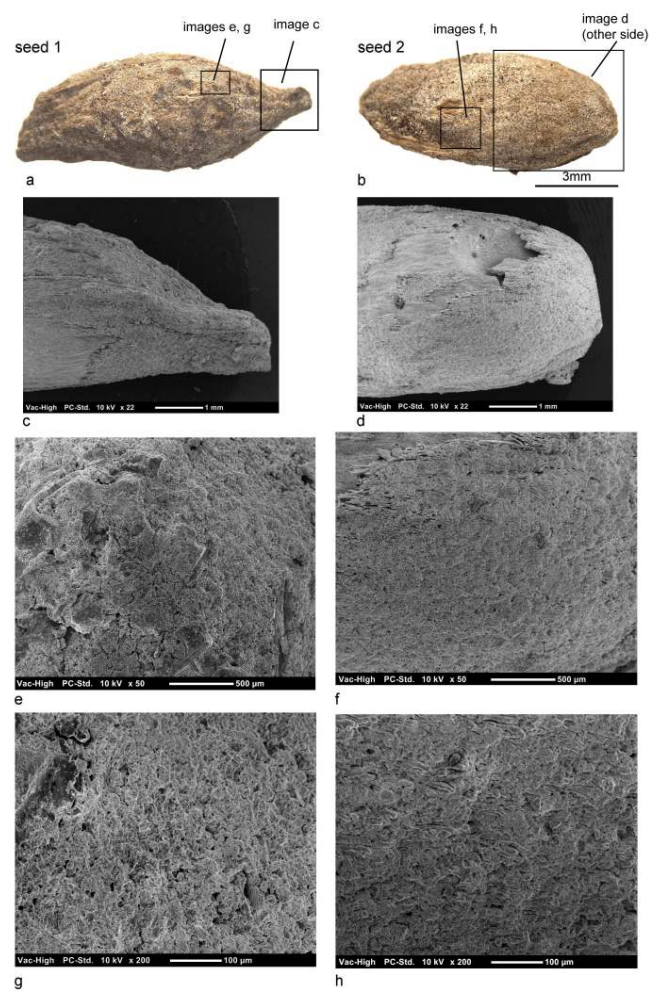

a-b. General view of the lateral side of the pips no 1 and no 2; c-d. Ventral view at magnification of 22x of the pips 1 and 2 showing the crest in the hilum region; e-h. Detail of the seed surfaces on the lateral side at magnifications of 50x and 200x (a-b: photo under stereomicroscope, Hallavant Hadès 2015; ch: images SEM Lemoine and Ruas CNRS UMR 7209 2016). 
Fig. 4 - Lateral view of an archaeological Citrus seed showing the position of the measurements and the anatomical part used as criteria for the taxonomical attribution. The breadth is taken from the ventral view of the seed (photograph C. Hallavant Hadès 2014).

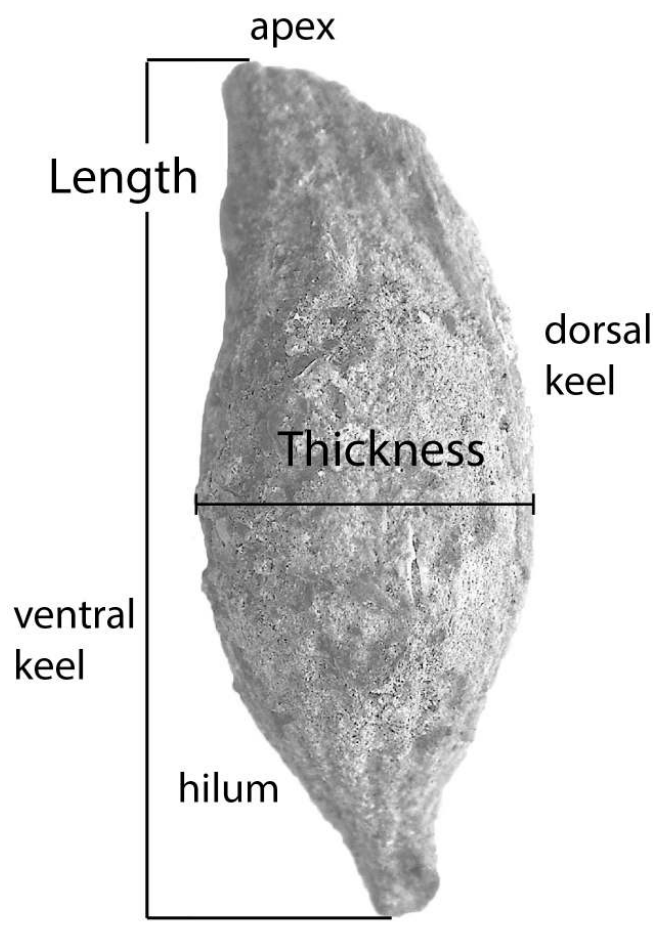

\section{radicle zone}

Despite their waterlogged state, the surface of the seeds was eroded. At a magnification of 50x and 200x, the cellular surface appears irregular, anarchic and lumpy, formed by irregular protrusions near the crest and base (fig. 3e-h). This appearance eliminates the possibility of it being lemon (C. $x$ limon) or citron (C. medica), as their cells are aligned in parallel longitudinal chains. ${ }^{130}$ On the other hand, it is reminiscent of the anarchical aspect of the surfaces of orange (C. $x$ aurantium), mandarin (C. reticulata) and lime (C.x aurantiifolia) seeds. The surface of the orange and lime seeds appears winding and this pattern is most pronounced on the orange. No winding pattern was visible on the Bordeaux seeds, which are closer to the pitted appearance of the mandarin seeds; however, it is possible that the surfaces were altered due to their prolonged contact with the accumulated matter in the ditch. Even though certain characteristics are reminiscent of orange seeds (the outline and curvature of the apex and the hilum zones), the anatomical details of the surfaces resemble the mandarin. Consequently, it is difficult to decide to which species of Citrus the archaeological seeds belong. Analysis of the tegument and cell pattern of these two seeds may suggest the identification Citrus $x$ aurantium/reticulata. The three other less well-preserved pips could also come from fruits of this taxon.

\subsubsection{Fruits of a wealthy family}

Although the area where food waste was discarded is located near a river port zone - a place where foodstuffs were imported from distant lands - a local source for the consumed fruits is also plausible. Indeed, growing orange trees in the Aquitaine region was fashionable among the nobility of Bordeaux during the $18^{\text {th }}$ century. Aristocratic 
families, newly-rich merchants and artisans living in the centre of the town acquired country houses on the outskirts of Bordeaux surrounded by pleasure gardens which included trees, bushes, local or exotic flowers and a fruit and vegetable garden. Some religious establishments (such as the convents of the Carthusians and Carmelites) had such remarkable gardens that they extended into the ecclesial space. Moreover, the aristocratic elite possessed orangeries and heated glasshouses, and purchased their plants from private or royal nurseries. Sheltered in winter and grown in oak boxes (as during the Middle Ages) or in earthenware pots from Anduze, citrus fruits from orangeries (orange, lemon and sour orange trees) were taken outside at the beginning of May to border the lawns and separate the vegetable garden from the pleasure garden, which was reserved for trees, bushes, flowers, fountains and statues. ${ }^{131}$ Having citrus on the table remained a privilege of the Aquitaine aristocracy with oranges being consumed initially during festive occasions and lemons being used as a condiment for sauces. Before the French Revolution these two luxury foodstuffs are mentioned in the Aquitaine account books and indicate that $30 \%$ of the fruits served at wealthy family tables were lemons and $25 \%$ were oranges. They were consumed fresh, in jams, in the form of candied peel, in ice cream and in main dishes, for their acidic juice. The lemons were also regularly used in religious establishments and hospitals. These citrus fruits originated either from local cultivations in the Aquitaine region or were imported from Portugal or Spain. ${ }^{132}$ Therefore it is possible that the seeds from the Saint-Michel site could have come from either a horticultural estate of a wealthy Bordeaux land owner or through Mediterranean commercial exchanges.

\section{Conclusion}

Although citrus fruits have existed and been consumed in western Europe since antiquity, the first archaeobotanical evidence found in this area dates back to the modern period. And though they were introduced in the south of medieval Spain, where they were grown directly in the ground, during the Arab conquest of the western Mediterranean, they were slow in coming to temperate Europe. Growing them in transportable boxes developed at the end of the Middle Ages in France, and elsewhere in temperate Europe. With regards to their consumption and cultivation, citrus fruit remained a luxury product especially in the north of Europe, as is stated in French and Italian culinary treatises. The absence of these remains in the landfills of medieval urban sites is probably due to the different ways of consumption (fruits were pressed for their juice, and their peel and pulp were candied), as well as to the often unfavourable preservation conditions resulting in the desiccation of organic waste. The recent history of these fruits, therefore, seems mostly clarified by written sources. 


\section{Sources}

Aebischer 1953: P. Aebischer, Un manuscrit valaisan du 'Viandier' attribué à Taillevent, Vallesia, 8, p. 73-100.

Bouas, Vivas 2008: F. Bouas, F. Vivas, Du fait de cuisine. Traité de gastronomie médiévale de Maître Chiquart, Arles.

Brereton, Ferrier 1994: G.-E. Brereton, J.-M. Ferrier (eds.), Le menagier de Paris, Paris.

Chiquart, Du fait de cuisine, Sion, Bibliothèque cantonale du Valais, S 103.

Enseingnemenz qui enseingnent a apareillier toutes manières de viandes... Paris, BnF, Lat. 7131.

Faccioli 1966: E. Faccioli (ed.), Arte della cucina. Libri di ricette, testi sopra lo scalco, il trinciante e i vini dal XIV al XIX secolo, vol. 1, Milan.

Frati 1899: L. Frati, Libro di cucina del secolo XIV, Livorno.

Gifreu 2013: G. Gifreu (fr. transl., ed.), Le livre de cuisine de Sent sovi, Perpignan.

Ibn Al-‘Awwām, Le livre de l'agriculture: Ibn Al-'Awwām, Le livre de l'agriculture Kitâb Al-Filâha, J.-

J. Clément (transl.), Arles.

Ibn Butlan, Tacuinum sanitatis (11 ${ }^{\text {th }}$ century), fac-sim., Liège, Bibl. Univ., ms. 1041.

Il Tacuinum sanitatis della Biblioteca Nazionale di Parigi (Paris, BnF, Nal. 1673), fac-sim. E. Berti Toesca, Bergamo, 1936.

Kosta-Théfaine 2009a: J.-F. Kosta-Théfaine (ed.), Le Vivendier, Clermont-Ferrand.

Kosta-Théfaine 2009b: J.-F. Kosta-Théfaine, Le Recueil de Riom (recettes de cuisine du XV siècle), Clermont-Ferrand.

Kosta-Théfaine 2010a: J.-F. Kosta-Théfaine (ed.), Nostradamus. Traité des confitures, Paris.

Kosta-Théfaine 2010b: J.-F. Kosta-Théfaine, Les Enseignements qui apprennent à préparer toutes sortes de plats (Les Enseingnemenz qui enseignent a apareiller toutes manieres de viandes). Recettes de cuisine du XIV siècle, Clermont-Ferrand.

La Framboisière 1669: N.-A. de La Framboisière, Les œuvres de N. Abraham de La Framboisière, Lyon, chez Pierre Bailly en ruë Mercière, à l'Enseigne de la Croix d'Or, 1669.

Lambert 1987: C. Lambert, Le Recueil de Riom et La Manière de enter soutillement : un livre de cuisine et un réceptaire sur les greffes $d u \mathrm{XV}^{e}$ siècle, Montréal.

Le Vivendier, Kassel, Gesamthochschul-Bibliothek, $4^{\circ}$ Ms. med. 1.

Liber de coquina, Paris, BnF, Lat. 7131, Lat. 9328; Vaticano, Bibl. Apost., Vat. Lat. 1768.

Libro della cocina dit aussi Anonimo toscano, Bologna, Bibl. Univ., ms. 158.

Libro per cuoco - Anonimo veneziano, Roma, Bibl. Casanatense, ms. 225.

Martino de' Rossi, Libro de arte coquinaria, in Faccioli 1966, p. 115-204.

Modus viaticorum preparandorum et salsarum, Paris, BnF, Lat. 8435.

Mulon 1971: M. Mulon, Deux traités inédits d'art culinaire médiéval, Bulletin philologique et historique (jusqu'à 1610) du Comité des Travaux historiques et scientifiques. Actes du $93^{e}$ Congrès national des Sociétés Savantes tenu à Tours, 1. Les problèmes de l'alimentation, Paris, p. 369-435. 
Nostradamus, Le vray et parfaict embellissement de la face suivi de la Seconde partie, contenant la façon et manière de faire toutes confitures liquides tant en succre, miel, qu'en vin cuit, Lyon, Antoine Volant, 1555 , Lyon, BM, fonds ancien, Rés 813538.

Opsomer 1991: C. Opsomer, L'art de vivre en santé. Images et recettes du Moyen Âge (Le Tacuinum sanitatis (Ms. 1041) de la bibliothèque de l'Université de Liège), Liège.

Peyrebonne 2011: N. Peyrebonne (fr. transl., ed.), Roberto de Nola. Le livre de cuisine, Paris.

Platearius, Livre des simples médecines: Platearius, Le livre des simples médecines, d'après le manuscrit français 12322 de la Bibliothèque nationale de Paris, G. Malandin (transl., ed.), F. Avril, P. Lieutaghi (eds.), Paris, 1986 (reed. 1990).

Poirion, Thomasset 1995: D. Poirion, C. Thomasset, L'art de vivre au Moyen Âge (Codex Vindobonensis series nova 2644, conservé à la Bibliothèque Nationale d'Autriche), Paris.

Recueil de Riom et la manière de henter soutillement, Paris, BnF, Lat. 6707.

Roberto de Nola, Libre del coch: Libre de doctrina per a ben servir, de tallar, y del Art de Coch: ço es de qualsevol manera de potages y salses. Compost per lo diligent mestre Robert coch del Serenissimo senyor don Fernando Rey de Napols, Barcelona, 1520.

Scully 1985: T. Scully, Du fait de cuisine par Maître Chiquart, 1420 (Ms. S 103 de la bibliothèque Supersaxo, à la Bibliothèque cantonale du Valais, à Sion), Vallesia, 40, p. 101-231.

Sent Sovi, Valence, Bibl. Univ., ms. 216; Barcelone, Bibl. Univ., ms. 68.

Theatrum Sanitatis, fac-sim. M. Salmi, A. Pazzini, E. Pirani, 3 vol., Parma, 1970-1971.

Theatrum Sanitatis, Vienne, ÖNB, Sn 2644; fac-sim. F. Unterkircher, Tacuinum sanitatis in medicina..., 2 vol., Paris-Graz, 1967.

Theatrum Sanitatis, Rome, Bibl. Casanatense, ms. 4182; fac-sim. L. Serra, S. Baglioni, Codice 4182 della R. Biblioteca Casanatense, 2 vol., Roma, 1940.

Théophraste, Recherches sur les plantes, t. II (livres 3-4), S. Amigues (ed., transl.), Paris, CUF, 1989.

Viandier, Sion, Bibliothèque cantonale du Valais, S 108.

Zambrini 1863: F. Zambrini (ed.), Il Libro della cucina del secolo XIV, Bologna, 1863 (reed. 1968).

Zanichelli et al. 1890: D. Zanichelli, G. Zanichelli, S. Morpurgo, LVII ricette d'un libro di cucina del buon secolo della lingua, Bologna.

\section{References}

Albertini 2013: L. Albertini, Essor de l'agriculture en Al-Andalus (Ibérie arabe), XV $V^{e}-X I V^{e}$ siècle. Performances des agronomes arabo-andalous, Paris.

Allard 1992: J. Allard, Nola : rupture ou continuité, in C. Lambert (ed.), Du manuscrit à la table. Essais sur la cuisine au Moyen Âge et répertoire des manuscrits médiévaux contenant des recettes culinaires, Paris-Montréal, p. 149-159.

Amigues 2010: S. Amigues, Théophraste, Recherches sur les plantes. À l'origine de la botanique, Paris. André 1981: J. André, L'alimentation et la cuisine à Rome, Paris.

Avril 1991: F. Avril, Giovanni Cadamosto da Lodi. Libro de componere herbe et fructi. Miniato in Italia settentrionale ante 1471 con aggiunte del 1474-1479, in A. Mottola Molfino, M. Natale (eds.), Le Muse e il Principe. Arte di corte nel Rinascimento padano, Modena, p. 209-210. 
Baumann 1974: F.A. Baumann, Das Erbario Carrarese und die Bildtradition des Tractatus de herbis, Berne.

Beneš et al. 2012: J. Beneš, V. Čulíková, J. Kosňovská, J. Frolík et J. Matiášek, New Plants at Prague Castle and Hradčany in the Early Modern Period: A History of Selected Species, Interdisciplinaria Archaeologica. Natural Sciences in Archaeology, 3, 1, p. 103-114.

Bériac 1989: J.-P. Bériac, Les jardins des Bordelais au XVIII ${ }^{\mathrm{e}}$ siècle, in Jardins et vergers 1989, p. $175-204$.

Bilimoff 2005: M. Bilimoff, Promenade dans des jardins disparus : les plantes au Moyen Âge d'après les Grandes heures d'Anne de Bretagne, Bibliothèque nationale de France, Ms. latin 9474, Rennes.

Bouby 2014: L. Bouby, L'agriculture dans le bassin du Rhône du Bronze final à l'Antiquité. Agrobiodiversité, économies, cultures, Toulouse.

Brunet, Redon 1990: J. Brunet, O. Redon, Vin, jus et verjus : du bon usage culinaire des jus de raisins à la fin du Moyen Âge, in Le vin des historiens, Suze-la-Rousse, p. 109-117.

Butzer et al. 1985: K.W. Butzer, J.E. Mateu, E.K. Butzer, P. Kraus, Irrigation Agrosystems in eastern Spain: Roman or Islamic origins, Annals of the Association of American Geographers, 75, 4, p. 479-509.

Capatti, Montanari 2002: A. Capatti, M. Montanari, La cuisine italienne : histoire d'une culture, Paris. Céard, Margolin 1986: J. Céard, J.-C. Margolin, Rébus de la Renaissance : des images qui parlent, 2. Rébus de Picardie. Les manuscrits Fr 5658 et 1600 de la Bibliothèque Nationale. Édition et commentaires, Paris.

Comet 1995: G. Comet, L'iconographie des «plantes nouvelles » en Europe, ou une approche des débuts de la botanique moderne, in Campagnes médiévales : l'homme et son espace. Études offertes à Robert Fossier, Paris, p. 45-57.

Ehlert 2002: T. Ehlert, Les manuscrits culinaires médiévaux témoignent-ils d'un modèle culinaire allemand ?, in M. Bruegel, B. Laurioux (eds.), Histoire et identités alimentaires en Europe, Paris, p. 121-136.

Flandrin 1984: J.-L. Flandrin, Internationalisme, nationalisme et régionalisme dans la cuisine des $\mathrm{XIV}^{\mathrm{e}}$ et $\mathrm{XV}^{\mathrm{e}}$ siècles : le témoignage des livres de cuisine, in Manger et boire au Moyen Âge. Actes du colloque de Nice, 15-17 octobre 1982, 2, Paris, p. 75-91.

Gras 1918: N.S.B. Gras, The early English customs system. A documentary study of the institutional and economic history of the customs from the $13^{\text {th }}$ to the $16^{\text {th }}$ centuries, Cambridge (Mass.).

Grieco 1987: A.J. Grieco, Classes sociales, nourriture et imaginaire alimentaire en Italie (XIVe-XVe siècles), Thèse de l'E.H.E.S.S., Paris.

Gual Camarena 1968: M. Gual Camarena, Vocabularie del comercio medieval. Collección de aranceles aduaneros de la Corona de Aragón (siglos XIII-XIV), Tarragone.

Hallavant 2014: C. Hallavant, Étude carpologique des niveaux modernes, in Sauvaitre 2014, p. 225-231, p. 269 (vol. 1), p. 396-400 (vol. 2), p. 257-263 (vol. 3).

Hernández Bermejo, García Sánchez 1998: J. Hernández Bermejo, E. García Sánchez, Economic Botany and Ethnobotany in Al-Andalus (Iberian Peninsula: Tenth-Fifteenth Centuries), an Unknown Heritage of Mankind, Economic Botany, 52, 1, p. 15-26.

Higounet-Nadal 1989: A. Higounet-Nadal, Les jardins urbains dans la France médiévale, in Jardins et vergers 1989, p. 115-144.

Impelluso, Sartarelli 2004: L. Impelluso, S. Sartarelli, La nature et ses symboles, Paris. 
Jardins et vergers 1989: Jardins et vergers en Europe occidentale (VIII ${ }^{e}-\mathrm{XVIII}{ }^{e}$ siècles). Actes des $9^{e}$ Journées internationales d'histoire du Centre culturel de l'abbaye de Flaran, 18-20 septembre 1987, Auch.

Lambert 1989: C. Lambert, La cuisine française au bas Moyen Âge : pays d'oïl vs pays d'oc, in J. Peltre, C. Thouvenot (eds.), Alimentation et régions, Nancy, p. 375-389.

Laurent 1978: H. Laurent, La draperie des Pays-Bas en France et dans les pays méditerranéens (XII $-\mathrm{XV}^{e}$ s.) , Brionne.

Laurioux 1988: B. Laurioux, Le « Registre de cuisine » de Jean de Bockenheim, cuisinier du pape Martin V, Mélanges de l'École française de Rome. Moyen Âge, Temps modernes, 100, 2, p. 709-760.

Laurioux 2006: B. Laurioux, Une histoire culinaire du Moyen Âge, Paris.

Levi d'Ancona 1977: M. Levi d'Ancona, The garden of the Renaissance: Botanical symbolism in Italian painting, Florence.

Mane 2005-2006: P. Mane, Les fruits dans les traités culinaires français (XIII ${ }^{\mathrm{e}}-\mathrm{XV}^{\mathrm{e}}$ siècles), Archéologie du Midi médiéval, 23-24, p. 129-144.

Mane 2006: P. Mane, Le travail à la campagne au Moyen Âge. Étude iconographique, Paris.

Mérindol 1993: C. de Mérindol, De l'emblématique et de la symbolique de l'arbre à la fin du Moyen Âge, in Pastoureau 1993, p. 105-125.

Meyzie 2007: P. Meyzie, La table du Sud-Ouest et l'émergence des cuisines régionales (1700-1850), Rennes.

Pächt 1991: O. Pächt, Le paysage dans l'art italien : les premières études d'après nature dans l'art italien et les premiers paysages de calendrier, Saint-Pierre-de-Salerne.

Pagnoux et al. 2013: C. Pagnoux, A. Celant, S. Coubray, F. Girolamo, V. Zech-Matterne, The introduction of Citrus to Italy, with reference to the identification problems of seed remains, Vegetation History and Archaeobotany, 22, p. 421-438.

Pastoureau 1993: M. Pastoureau (ed.), L'arbre. Histoire naturelle et symbolique de l'arbre, du bois et du fruit au Moyen Âge, Paris.

Puig 2003: C. Puig, Les campagnes roussillonnaises au Moyen Age : dynamiques agricoles et paysagères entre le XII ${ }^{e ̀ m e}$ et la première moitié $\mathrm{du}$ XIV ${ }^{\text {ème }}$ siècle, Thèse de doctorat d'Histoire, Université de Toulouse-Le Mirail.

Puig 2006: C. Puig, La place des fruits en Méditerranée nord-occidentale à partir des actes de la pratique et des tarifs marchands (XII ${ }^{\mathrm{e}}$-première moitié XIV ${ }^{\mathrm{e}}$ siècles), Archéologie du Midi médiéval, 23-24, p. 119-128.

Ramón-Laca 2003: L. Ramón-Laca, The introduction of cultivated Citrus to Europe via northern Africa and the Iberian Peninsula, Economic Botany, 57, 4, p. 502-514.

Ruas 1996: M.-P. Ruas, Éléments pour une histoire de la fructiculture en France au Moyen Âge : données archéobotaniques de l'Antiquité au XVII ${ }^{\mathrm{e}}$ siècle, in M. Colardelle (ed.), L'homme et la nature au Moyen Âge. Actes du $V^{e}$ Congrès international de la Société d'Archéologie médiévale, Grenoble, octobre 1993, Paris, p. 92-105.

Ruas et al. 2015: M.-P. Ruas, P. Mane, C. Puig et al., Regard pluriel sur les plantes de l'héritage arabo-islamique en France médiévale, in C. Richarté, R.-P. Gayraud, J.-M. Poisson (eds.), Héritages arabo-islamiques dans l'Europe méditerranéenne, Paris, p. 347-376.

Santich 1984: B. Santich, L'influence italienne sur l'évolution de la cuisine médiévale catalane, in Manger et boire au Moyen Âge. Actes du colloque de Nice, 15-17 octobre 1982, 1, Paris, p. 131-139. 
Sauvaitre 2014: N. Sauvaitre (ed.), Espace Saint-Michel. Bordeaux (Gironde), Rapport final d'opération archéologique Hadès, 3 vol., Service régional de l'archéologie d'Aquitaine, Bordeaux.

Schoch 1996: W. Schoch, Eleonora 1568-1580. Botanische Makroreste aus den Grab, Labor für Quartaere Hoelzer. Adliswil. MS., unpublished report.

Tarayre 2006: M. Tarayre (ed.), Jérôme Münzer. Voyage en Espagne et au Portugal (1494-1495), Paris.

Tolkowsky 1938: S. Tolkowsky, Hesperides. A history of the culture and use of citrus fruit, London.

Toresella 1985: S. Toresella, Il codice di Giovanni Cadamosto, L'Esopo, 27, p. 45-64.

Van der Veen 2011: M. Van der Veen, Consumption, Trade and Innovation: Exploring the Botanical Remains from the Roman and Islamic Ports at Quseir al-Qadim, Egypt, Frankfurt.

Wiethold 2003: J. Wiethold, How to trace the 'romanisation' of central Gaule by archaeobotanical analysis? Some considerations on new archaeobotanical results from France centre-est, in F. Favory, A. Vignot (eds.), Actualités de la recherche en histoire et archéologie agraires. Actes du Colloque international AGER V, Besançon, septembre 2000, Besançon, p. 269-282.

Wiethold 2005: J. Wiethold, Botanische Funde aus der Nonnenempore des Klarissenklosters von Ribnitz, Kr. Nordvorpommern, und aus dem Haus Mönchstr. 38, Hansestadt Stralsund. Zwei Beispiele für die Auswertung und Interpretation von botanischen Funden aus Gebäuden, in I. Ericsson, R. Atzbach (eds.), Depotfunde aus Gebäuden in Zentraleuropa. Concealed finds from buildings in Central Europe. Bamberger Kolloquien zur Archäologie des Mittelalters und der Neuzeit 1, Berlin, p. 131-146.

Wilson 1973: C.A. Wilson, Food and drink in Britain from the Stone Age to recent times, Harmondsworth.

Zech-Matterne 2010: V. Zech-Matterne, Le développement de la fructiculture en Gaule du Nord, à l'époque romaine, in P. Ouzoulias, L. Tranoy (eds.), Comment les Gaules devinrent romaines, Paris, p. 255-266.

\section{NOTES}

1. Cf. articles of this book.

2. Cf. Van der Meer, this book.

3. Mane 2006; Puig 2006.

4. Ruas 1996; Wiethold 2003; Zech-Matterne 2010; Bouby 2014.

5. Hallavant 2014.

6. Cf. § 2 .

7. Mane 2005-2006.

8. Flandrin 1984.

9. The same name may have been given to different preparations, as recipe preparations differ from one book to another.

10. Grieco 1987: 157-158.

11. Bruno Laurioux (Laurioux 1988) remembers how disappointed Saint Bernardino of Siena was (Bt X, 17, s.v. melarancia) when, after tasting an orange, he was obliged to spit it out because the taste was so bitter ("amaro e ostica").

12. Mulon 1971: 369-435.

13. Also called "Anonimo toscano" Recipe 129, and also 126, 127, 129, 133, 153.

14. Laurioux 1988.

15. Brunet, Redon 1990. 
16. Paris, BnF, Lat. 9474, fol. 168.

17. Recipe 29. Translated into English (transl. J. Cucchi).

18. Around 1555 in his book Livre des confitures. Translated into English (transl. J. Cucchi).

19. Tolkowsky 1938: 234-249.

20. Translated into English (transl. J. Cucchi).

21. Lambert 1989.

22. Puig 2006: 120.

23. Remember that the Collioure tarif was used as a model in Tortose, which explains the matching tax lists (leudaires) coming from these two cities.

24. In any case, the products indicated are essentially from the Mediterranean area, with no trace of products coming from the North (cloth manufacturing, for example, arrived in this region during the $13^{\text {th }}$ century: Laurent 1978: 109-110).

25. M. Gual Camarena proposes to furnish a complete transcription of the Catalan tariffs and a full dictionary: Gual Camarena 1968.

26. Mane 2006: 29-72 and 259-261.

27. Comet 1995. Translated into English (transl. J. Cucchi).

28. Van der Veen 2011: 83-84 ; Schoch 1996, unpublished and cited by Beneš et al. 2012, and cf. in this book.

29. See, for example, the discoveries of squeezed fruit and seeds (probably from lemons or limes, Citrus cf. aurantiifolia) from the Islamic rubbish dump at the Quseir al-Qadim site in Egypt: Van der Veen 2011: 83-84.

30. Pagnoux et al. 2013: 431.

31. Hernández Bermejo, García Sánchez 1998 : 23, tab.2; Ramón-Laca 2003: 504-511; Albertini 2013: 228-235.

32. Comet 1995. Translated into English (transl. J. Cucchi).

33. This work has other titles: Liber de simplicibus medicinis or Secreta salernitana.

34. This number changes from one copy to the next (cf. Platearius, Livre des simples médecines: 284 sqq.).

35. Baumann 1974 divided the copies of Livre des simples médecines into three groups according to whether they came from northern France, from the Burgundy states (Artois, Picardy and Flanders region) or from the west of France.

36. Platearius, Livre des simples médecines: 268. Translated into English (transl. J. Cucchi).

37. Pächt 1991: 22.

38. Paris, BnF, Naf. 6593, fol. 73v; Fr. 623, fol. 67; Fr. 12320, fol. 56; and Fr. 19081, fol. 56.

39. Paris, BnF, Fr. 1307, fol. 93; Fr. 1311, fol. 11; Fr. 9137, fol. 109v; or Fr. 12322, fol. 194v.

40. As in some Burgundy copies (Paris, BnF, Naf. 6593, fol. 73v; or Fr. 9137, fol. 109v), but also products in northern France or Flanders (Paris, BnF, Fr. 9136, fol. 82v; Fr. 12319, fol.115v; Fr. 12320, fol. 56; or Fr. 19081, fol. 56).

41. Like the two copies produced in western France (Paris, BnF, Fr.1307, fol.93; and Fr. 1311, fol. 11).

42. Paris, BnF, Fr. 623, fol. 67.

43. Paris, BnF, Naf. 6593, fol. 73v; or Fr. 9136, fol. 82v.

44. Paris, BnF, Fr. 623, fol. 67.

45. Platearius, Livre des simples médecines: 323.

46. Paris, BnF, It. 1108, fol. 46v. Cf. Toresella 1985; Avril 1991.

47. New York, Pierpont Morgan Libr., ms. 873, fol. 59v.

48. For example, Paris, BnF, Nal. 1673, or Vienne, ÖNB, Sn 2644.

49. Liege, Bibl. Univ., ms. 1041.

50. Paris, BnF, Nal. 1673.

51. Fol. 15v. 
52. Fol. 18v.

53. Fol. 18.

54. Fol. 82v.

55. Designated by "zetrona" or "cetron" in a Tacuinum, carried out in Rhineland around 1445 (Paris, BnF, Lat. 9333), predominantly inspired by the Lombard copy which was illuminated around 1390 (Vienne, ÖNB, Sn 2644).

56. Called "citra vel citrea mala" or "zitrinaten" in the Rhenan copy. In this book (Paris, BnF, Lat .9333 , fol. 16) the colour of the lemons is more green than yellow.

57. Vienna, ÖNB, Sn 2644, fol. 11; or Paris, BnF, Lat. 9333, fol. 8.

58. Paris, BnF, Nal. 1673, fol. $15 \mathrm{v}$.

59. Paris, BnF, Lat. 9474, fol. 168.

60. Bilimoff 2005: 48.

61. Paris, Louvre museum, former Campana collection, Campana 50.

62. Paris, Louvre museum, former Campana collection, Campana 49, or on an enamelled baked clay or terracotta medallion showing La tempérance, where oranges, pine cones, quinces, grapes are drawn on the raised sides (Écouen, musée national de la Renaissance, inv. E Cl. 2068).

63. See this volume.

64. Theophrastus, RP, IV, 4, 3; André 1981: 79; Amigues 2010: 139.

65. Van der Veen 2011: 80.

66. Butzer et al. 1985: 500, 502; Hernández Bermejo, Garcia Sánchez 1988: 23, tab. 2.

67. Ibn Al-'Awwām, Le livre de l'agriculture: 257. Name specified in the French translation by J.J. Clément.

68. Ramón-Laca 2003: 504-511.

69. Ibn Al-'Awwām, Le livre de l'agriculture: 257.

70. Higounet-Nadal 1989.

71. Tarayre $2006: 42$.

72. Vienne, ÖNB, ms. 2396, fol. $5 \mathrm{v}$.

73. Ruas et al. 2015: 364.

74. Flandrin 1984.

75. The first times that sour oranges are mentioned goes back to the $16^{\text {th }}$ century in the Kochbuch der Sabina Walrein (Ehlert 2002).

76. For example no mention in the Forme of Cury, written around 1390 by the chef to King Richard II or Liber cure cocorum, written in Lancashire between 1422 and 1471.

77. Written at the beginning of the $14^{\text {th }}$ century in France, probably in Paris (Paris, BnF, Lat .7131).

78. Written in France during the first half of the $14^{\text {th }}$ century.

79. Lambert 1987.

80. Kosta-Théfaine 2009a.

81. Paris, BnF, Fr. 12477 (Brereton, Ferrier 1994).

82. See recipe 193. In the Catalan treatise, the Sent Sovi, a sauce containing bitter orange juice is served with fried fish. The expression "orange verjus" is also used in Italian cookbooks. It seems that one recipe used sour tasting varieties, as confirmed in dietary books.

83. However in this recipe, the fish must be cooked in water and not fried, which does not correspond to Mediterranean habits.

84. Capatti, Montanari 2002: 105; Laurioux 2006: 357-373.

85. Paris, BnF, Lat. 8435.

86. This recipe is in two Catalan cooking treatises under the names "limoneha" and "limonada".

87. Also called Anonimo veneziano (Frati 1899).

88. Two hand written versions of this text exist: Valence, Bibl. Univ., ms. 216, and Barcelona, Bibl. Univ., ms. 68. Cf. Gifreu 2013. 
89. This book is known thanks to its edition in Catalan from Barcelona in 1520: Libre de doctrina per a ben servir, de tallar, $y$ del Art de Coch: ço es de qualsevol manera de potages y salses. Compost per lo diligent mestre Robert coch del Serenissimo senyor don Fernando Rey de Napols, and the Castillan text edited in Toledo in 1525: Libro de cocina compuesto por Ruberto de Nola... in 1529 entitled Libro de guisados, manjares y potajes intitulado Libro de Cozina, transl. and ed. in French: Peyrebonne 2011.

90. The court of Naples had been managed by the House of Aragon since 1442.

91. Santich 1984; Allard 1992.

92. "Per conciar starne al modo catalano": Martino de' Rossi, Libro de arte coquinaria, chapter 132 (Faccioli 1966: 127).

93. L'aygua-sal du Sent Sovi, chapters 28 and 140.

94. Chapter 30. To dilute the basil and pepper in a sauce for a roast, the author gave the following advice when verjuice was lacking: "si tu en manques, procure-toi des oranges, des cédrats ou des citrons "(Zambrini 1863: 79).

95. "Per fare carbonata": Martino de' Rossi, Libro de arte coquinaria, chapter 131 (Faccioli 1966: 127).

96. Zanichelli et al. 1890.

97. Lambert 1987: 375-384.

98. Puig 2003: 127. Translated into English (transl. J. Cucchi).

99. Wilson 1973: 332.

100. Gras 1918: 514-564.

101. Levi d'Ancona 1977; Pastoureau 1993; Impelluso, Sartarelli 2004.

102. Venice, Accademia.

103. Washington, National Gallery of Art, or, in 1501, in the background of the Vergine cucitrice painted by Giovanni Francesco Caroto (Modena, Galleria Estense).

104. Milan, Brera Museum.

105. Originally from the high-altar of Santa Maria church in Organo, Verona, it is now housed in the Civico museo d'Arte antica, Sforza Castle Museum, Milan.

106. Around 1457, Verona, Basilica of San Zeno Maggiore.

107. The State Hermitage Museum Petersburgh'.

108. Joos Van Cleve, Virgin and Child, ca. 1525 (New York, The Metropolitan Museum of Art, The Jack and Belle Linsky Collection, 1982.60.47), or from the same artist's workshop, The Holy Family, ca. 1527-33 (New York, The Metropolitan Museum of Art, The Robert Lehman Collection, 1975.1.117).

109. The State Hermitage Museum Petersburgh', or The Holy Family painted by Joos Van Cleve (London, The National Gallery).

110. Basel, Kunstmuseum.

111. The predella of the altarpiece The Communion of the Apostles (Urbino, National Gallery of the Marches, Sale di rappresentanza).

112. Paris, Cluny Museum, CL. 2240 , or a pharmaceutical jar of the $15^{\text {th }}$ century decorated with orange slices (Louhans, Hôtel-Dieu, inv. HD 91-1-658).

113. Mérindol 1993.

114. Besides being on the coat of arms, orange trees were illustrated on the drapery of Jean I de Berry: "de six tappiz vers, semez d'orengiers, et ou mislieua un orengier auqel pend un escu aux armes de feu mondit seigneur".

115. Lemon and orange trees are also painted on the walls of the Belligan manor built for Yolande of Aragon, daughter of King René. Besides the decors integrating orange trees, some texts mention gift of holly branches garnished with oranges made by René d'Anjou for Jeanne de Laval in June 1471.

116. Paris, BnF, Fr. 5658, fol. 125; and Fr. 1600, fol. 123.

117. Céard, Margolin 1986, p. 289.

118. La Framboisière 1669: 81. 
119. See Pagnoux, this book.

120. See Van der Meer, this book.

121. Beneš et al. 2012.

122. Schoch 1996 (quoted by Beneš et al. 2012).

123. Wiethold 2005.

124. Sauvaitre 2014.

125. The MNI (Minimal Number of Items) was calculated by adding the number of fragments divided by the number of whole seeds $[\mathrm{MNI}=$ number of whole seeds + (number of seed fragments/2)].

126. Abstract following Sauvaitre 2014 (vol. 1): 62.

127. Pagnoux et al. 2013.

128. Equipment granted by the Île-de-France Region and based in the archaeobotanical laboratory of the UMR 7209 CNRS-Muséum-Sorbonne-Universités, Paris.

129. Pagnoux et al. 2013.

130. Pagnoux et al. 2013: 433, fig. 8 A and B.

131. Bériac 1989: 195-196.

132. Meyzie 2007: 260-261.

\section{AUTHORS}

MARIE-PIERRE RUAS

CNRS, UMR 7209 CNRS-Muséum-Sorbonne-Universités, AASPE, Paris; ruas@mnhn.fr

\section{PERRINE MANE}

CNRS, UMR 8558, CNRS-EHESS, Centre de Recherches Historiques, Paris; Perrine.Mane@ehess.fr

CHARLOTTE HALLAVANT

HADES, Terrae UMR 5608 CNRS-Université Toulouse JJ - EHESS - Culture - INRAP, Toulouse;

challava@univ-tlse2.fr

\section{MICHEL LEMOINE}

CNRS, UMR 7209 CNRS-Muséum-Sorbonne-Universités, AASPE, Paris; lemoine@mnhn.fr 